\title{
Carbonate drowning successions of the Bird's Head, Indonesia
}

\author{
David P. Gold ${ }^{1}$ Peter M. Burgess ${ }^{2} \cdot$ Marcelle K. BouDagher-Fadel $^{3}$
}

Received: 29 March 2017 / Accepted: 21 July 2017 / Published online: 31 July 2017

(C) The Author(s) 2017. This article is an open access publication

\begin{abstract}
Drowning unconformities and their related strata are important records of key tectonic and environmental events throughout Earth's history. In the eastern Bird's Head region of West Papua, Indonesia, Middle Miocene strata record a drowning unconformity present over much of western New Guinea, including several offshore basins. This study records platform carbonate strata overlain by mixed shallow- and deep-water units containing benthic and planktonic foraminiferal assemblages in several outcrop locations across the eastern Bird's Head region. These heterolithic beds are interpreted as drowning successions that are terminated by a drowning unconformity. We define a succession exposed along the Anggrisi River in the eastern Bird's Head as a stratotype for carbonate platform drowning in the Bird's Head, analogous to similar faunal turnovers identified in its offshore basins. Detailed facies analyses, biostratigraphic dating, and paleoenvironmental interpretations using larger benthic and planktonic foraminifera collected from the Anggrisi River succession help to constrain the drowning event recorded onshore as beginning in the Burdigalian and ending in the Serravallian. The cause of platform drowning in the Bird's Head is attributed to a reduction in the rates of carbonate accumulation due to the presence of excess nutrients in the depositional
\end{abstract}

David P. Gold

david.patrick.gold@gmail.com

1 SE Asia Research Group, Department of Earth Sciences, Royal Holloway, University of London, Egham, Surrey TW20 0EX, UK

2 School of Environmental Science, University of Liverpool, Brownlow Street, Liverpool L69 3GP, UK

3 Office of the Vice-Provost, University College London, 2 Taviton Street, London WC1H 1BT, UK environment. Already foundering carbonate platforms due to environmental deterioration were left vulnerable to submergence and eventually succumbed to drowning. Low rates of carbonate production were outpaced by the rate of relative sea-level rise caused by high-amplitude oscillations in global glacio-eustatic sea-level change and/or regional tectonic subsidence. The duration of the drowning event across the entire Bird's Head region is interpreted to have lasted a duration of approximately $9.5 \mathrm{My}$, between 18.0 and $8.58 \mathrm{Ma}$. This has implications when interpreting timings of sedimentary basin fill across western New Guinea and in other basins where carbonate platform drowning is recorded.

Keywords Platform drowning - Drowning unconformity · Biostratigraphy $\cdot$ Carbonates $\cdot$ Foraminifera $\cdot$ Indonesia

\section{Introduction}

The concept of drowning unconformities is well established and there are many examples of carbonate platform drowning strata documented in the rock record worldwide (e.g., Schlager 1981, 1989; Hallock and Schlager 1986; Longman et al. 1987; Simone and Carannante 1988; Erlich et al. 1990, 1993; Föllmi et al. 1994; Drzewiecki and Simo 1997; Weissert et al. 1998; Blomeier and Reijmer 1999; Wortmann and Weissert 2000; Wissler et al. 2003; Ruiz-Ortiz et al. 2004; Mutti et al. 2005; Föllmi and Gainon 2008; Sattler et al. 2009; Najarro et al. 2011; Marino and Santantonio 2010; Brandano et al. 2016; Sulli and Interbartolo 2016). Carbonate platforms are defined as flat-topped accumulations of carbonate sediments developed at or very near sea level (Hallock and Schlager 1986). These platforms are complex natural 
systems that are sensitive to a number of environmental factors that may contribute to drowning. Environmental stresses that may lead to carbonate platform demise and the formation of drowning unconformities include oceanic anoxic events, tectonism and flexural loading, hyper- and hypo-salinity, change in carbon dioxide content of the oceans or atmosphere, change in nutrient supply, death of zooxanthellae, temperature, hydrodynamics, turbidity, light penetration, and evolutionary modification (Schlager 1991; Thorne 1992; Hallock and Schlager 1986; Erlich et al. 1990, 1993; Mutti et al. 2005). In all cases, however, platform drowning occurs because the rate of platform top production and accumulation is exceeded by the rate of relative sea-level rise, either because the rate of relative sea-level rise has increased, or because the rate of carbonate production has decreased. The process of carbonate platform drowning presents somewhat of a paradox as rates of carbonate production and accumulation normally exceed rates of long-term sea-level rise and subsidence; glacioeustatic sea-level rises, on the other hand, can exceed carbonate production (Schlager 1981; Hallock and Schlager 1986; Föllmi et al. 1994; Wissler et al. 2003; Ruiz-Ortiz et al. 2004; Mutti et al. 2005; Brandano et al. 2016). Kim et al. (2012) demonstrated that even if the rate of relative-sea level rise is lower than maximum carbonate potential platform drowning can still occur if accumulation rates at the initiation of drowning are lower than the rate of relative sea-level rise. This can be induced by slow response times of carbonate-producing marine benthic organisms to re-colonize the platform top after flooding. The time required for biotic colonization controls the increase in water depth which, in turn, determines carbonate production in a keep-up mode that is directly followed by drowning (Kim et al. 2012). These slow response times cause negative feedback in the rates of carbonate accumulation, which decrease exponentially with increasing water depth. This scenario serves as a possible explanation for the 'drowning paradox', where there is no evidence for significant external forcing, such as tectonic activity or glacio-eustatic changes (Kim et al. 2012). A drowning unconformity may be produced above a drowned platform through sediment starvation leading to a condensed section or progressive onlap by aggrading strata (Bosence et al. 1998; Ruiz-Ortiz et al. 2004) or progradation of siliciclastic strata, abruptly terminating carbonate production (Schlager 1989; Erlich et al. 1990, 1993).

In this paper, we present outcrop evidence analogous to interpreted drowning successions occurring in sedimentary basins from on- and offshore New Guinea. We provide ages and a causal interpretation for the drowning event of New Guinea by comparing sedimentological and biostratigraphic data from outcrop samples and review of well data.

\section{Physical characteristics of drowning strata}

Features of successions deposited during relative sea-level driven drowning may include a gradational lower and upper contacts, chemical sedimentation (e.g., glauconite, phosphate, ferruginous crusts), open-marine shelf sediments, a variable hiatus at the upper boundary, late-stage shelf-margin growth and sub-horizontal basinal marine onlap (Erlich et al. 1990, 1993). Drowning events can appear in outcrop to occur abruptly due to a sudden shutdown of carbonate platforms through environmental deterioration. However, they may also occur gradually, as younger platforms backstep conformably to continue accumulating in areas with more favorable environmental conditions (Erlich et al. 1990, 1993). In most scenarios, the drowning sequence appears gradational and typically includes a change in lithology from shallow-water carbonates to deeper-water siliciclastics or pelagic sediments of variable composition. These strata define a deepening-upwards sequence. During the drowning process, as water depths increase, shallow and deep-water lithologies may mix, producing short 'drowning successions' of heterolithic beds (Schlager 1989). These interbedded sequences are intermediate between platform carbonates and fully deep-water sediments, which contain a mix of benthic and planktonic carbonate factory products, marking the inception and completion of the drowning process (Marino and Santantonio 2010).

\section{Seismic expression of drowning strata}

In seismic reflection data, drowning unconformities have a similar seismic character to subaerial unconformities (type 1 sequence boundaries). These features include highamplitude reflections produced by the contrast in acoustic impedance between the deep- and shallow-water facies above and below the boundary, or presence of condensed sections, and both display marine onlap at the base of the platform margin (Schlager 1989). In traditional sequence stratigraphic interpretations, drowning unconformities are usually considered equivalent to marine flooding surfaces and may occupy opposite positions in the relative sea-level cycle to type 1 sequence boundaries (Van Wagoner et al. 1988; Erlich et al. 1990, 1993; Catuneanu 2006; Masse and Fenerci-Masse 2011). Schlager (1999) sought to define drowning unconformities as a third major boundary type, a 'type 3 sequence boundary', prone to forming long marine hiatuses and exhibiting high reflectivity in seismic sections. Drowning unconformities can be distinguished from other sequence boundaries by the retrogradational stacking pattern of carbonate platform margins that typically signify backstepping (Burgess et al. 2013), in contrast to the traditional incised valleys, coastal onlap, and forced regressive surfaces of type 1 sequence boundaries. Since carbonate strata 
backstep during drowning, the drowning unconformity can form diachronously across the platform top and will show a variable hiatus, depending on when and where subsequent deposition of deeper-water strata begins (e.g., Föllmi et al. 1994).

\section{Geological history}

The Pacific island of New Guinea is often described as having the appearance of a bird in map view. Papua New Guinea comprises the 'Bird's Tail' in the east, and the Indonesian provinces of West Papua and Papua comprise the 'Bird's Head', 'Neck' and 'Shoulder' to the west. The 'Bird's Neck' forms the Cenderawasih Bay embayment, to the north of which are located the islands of Yapen, Biak, and Supiori (Fig. 1). Several sedimentary basins are found within the Bird's Head, namely the Bintuni, North Irian, and Salawati Basins (Fig. 1). The Salawati and Bintuni Basins, to the west of the Bird's Head, are known to produce hydrocarbons. The Bird's Head region is a region of active tectonic deformation that is the result of interaction between the Eurasian, Pacific, and Australian plates, as well as several smaller microplates (Visser and Hermes 1962; Dow and Sukamto 1984; Pieters et al. 1983; Cloos et al. 2005), dissected by several major, mainly strike-slip, fault zones (Fig. 1).

The majority of New Guinea was part of the northern promontory of the Australian continent termed the Sula Spur during the Paleogene (Hall 2002, 2012). In eastern New Guinea, collision occurred between intra-Pacific island arcs formed above a northward-dipping subduction zone, and the Sula Spur during the latest Chattian-Aquitanian (Dewey and Bird 1970; Dow 1977; Pigram and

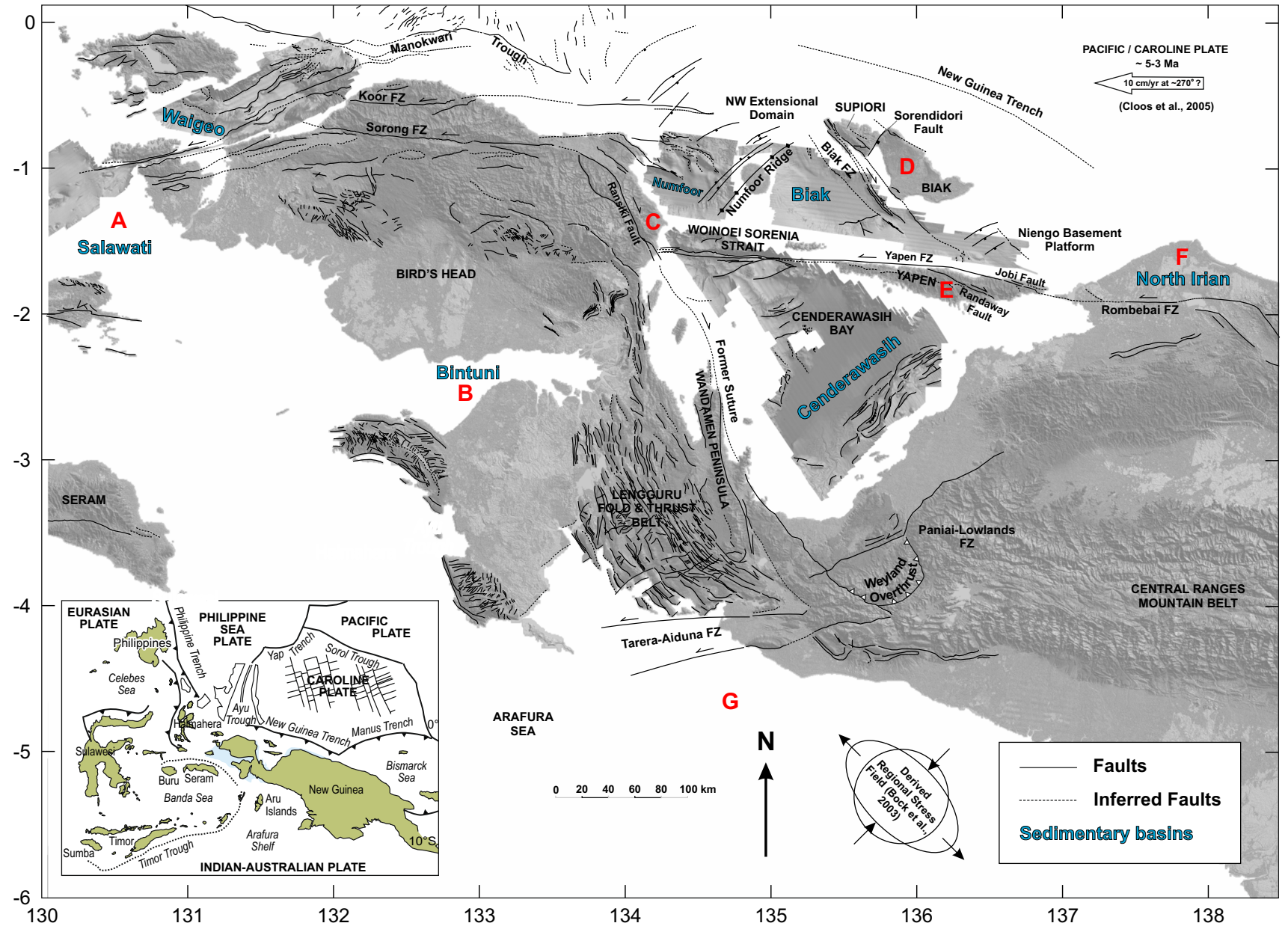

Fig. 1 Structural map of western New Guinea. Faults were drawn based on features identified from ASTER digital elevation data, bathymetric multibeam, and seismic data of the Biak and Cenderawasih Bay Basins provided by TGS, and those encountered in the field. The offshore Manokwari Trough was drawn from GLORIA sonar imagery (after Milsom et al. 1992). Derived regional stresses are implied after Bock et al. (2003), and vector of Pacific-Caroline plate motion plotted after Cloos et al. (2005). Letters $A-G$ correspond to stratigraphic columns of Fig. 2 
Davies 1987; Milsom et al. 1992; Hall 2002, 2012; Hill and Hall 2003; Wallace et al. 2004). Evidence of this arccontinent collision can be found in the eastern Bird's Head where a proposed suture between accreted arcs and the Australian continental margin is presently represented by the Ransiki Fault, interpreted to extend into Cenderawasih Bay, east of the Wandamen Peninsula, and link with the Weyland Overthrust in the New Guinea Central Ranges (Pigram et al. 1982; Dow and Hartono 1982; Milsom 1991, 1992; Fig. 1). The island arc rocks are represented by the Arfak Volcanics east of the Ransiki Fault in the eastern Bird's Head, and the Yapen Volcanics and Auwewa Formation found on Biak and Supiori (Fig. 2). These arc rocks now form the basement to much of the northern New Guinea margin including the eastern Bird's Head, Cenderawasih Bay, and its islands (Fig. 2). Similar sequences of these rock types have been interpreted as part of an ophiolite suite (Dow and Hartono 1982; Pieters et al. 1983; Hall 2002; Hill and Hall 2003; Cloos et al. 2005), abducted on to the New Guinea Central Ranges along the Weyland Overthrust (Fig. 1).
During this time, the Sorong Fault Zone (Fig. 1) was initiated when the Philippine Sea Plate began its clockwise rotation, at approximately $20 \mathrm{Ma}$, causing its southern boundary to change from one of subduction to sinistral strike-slip (Ali and Hall 1995; Hall 2002). The Sorong Fault forms the northern margin of the Salawati Basin (Redmond and Koesoemadinata 1976; Phoa and Samuel 1986), which is dominated by east-west folds and a complex interplay of strike-slip and extensional faults (Gibson-Robinson and Soedirdja 1986; Wilson 2006).

Arc-continent collision produced a subaerial, erosional, and angular Early Miocene unconformity (Fig. 2) and several compressional structures across northern New Guinea. In the Biak Basin (Fig. 1), this unconformity is marked by a subaerial erosion surface in which folded and thrusted island arc material deformed during the collision was uplifted and exposed leading to the erosional truncation of ramp anticlines with up to $820 \mathrm{~m}$ of section missing (Gold et al. 2014). The reduction of island arc material by erosion created platforms on which coral reefs flourished and platform carbonates developed (Wilson 2002). These

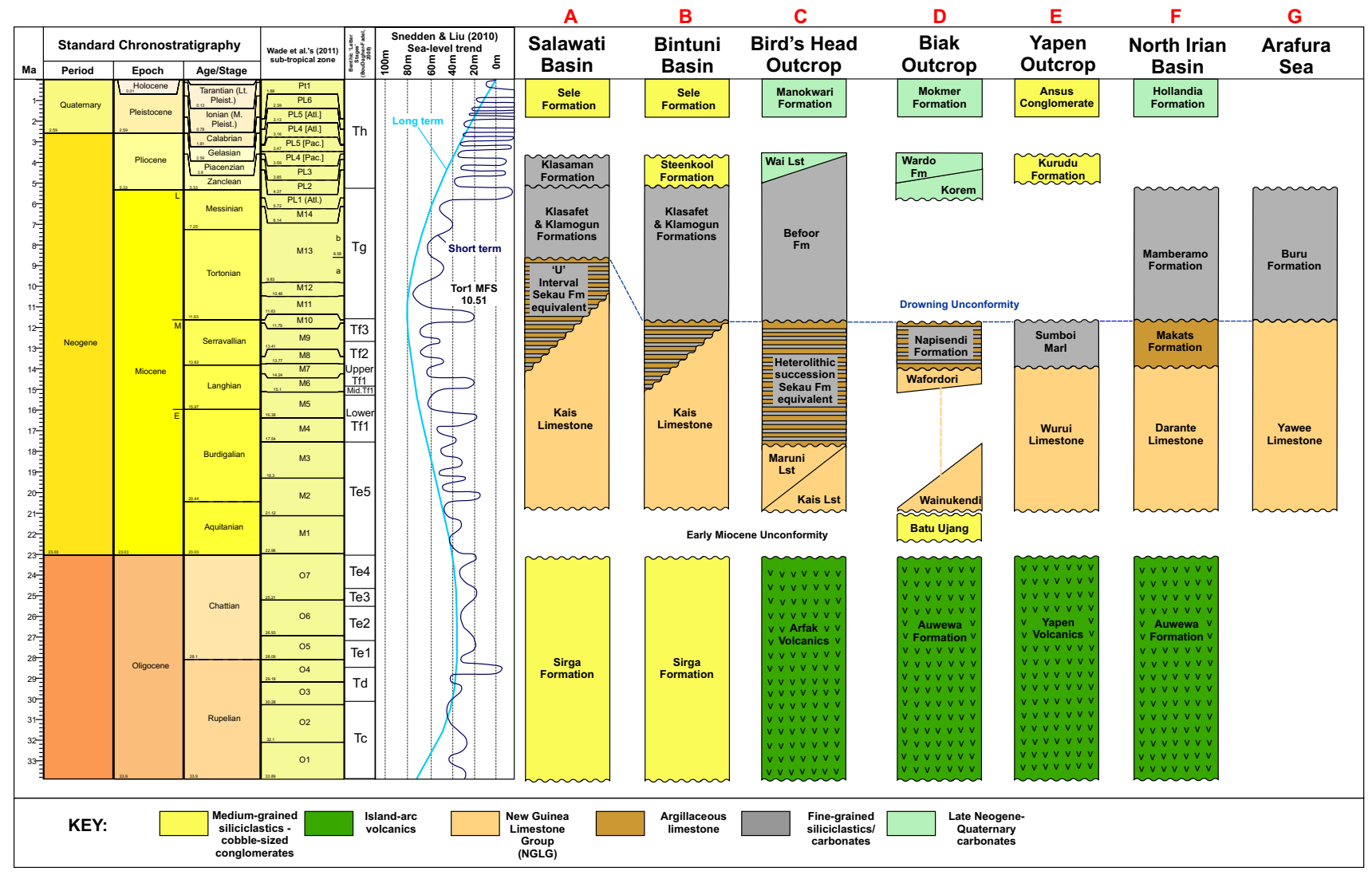

Fig. 2 Stratigraphy of the Bird's Head study area. Correlation of the stratigraphy indicates younging of the drowning unconformity from east to west. Stratigraphy derived from field and biostratigraphic data of this study and composites from listed authors (after Gibson-Robinson and Soedirdja 1986; Chevallier and Bordenave 1986; Waschmuth and Kunst 1986; Atmawinata et al. 1989). Sea-level curve of Snedden and Liu (2010), Indo-Pacific letter stages from BouDagher-Fadel (2008), stratigraphic columns and planktonic foraminiferal zones from Wade et al. (2011) and Timescale Creator (version 6.1.2, http:// www.tscreator.org) following the timescale of Gradstein et al. (2012) 
carbonate platforms developed across the region during early to middle Miocene slow relative sea-level rise, depositing the 'New Guinea Limestone Group' (NGLG) that includes several contemporaneous carbonate formations (Visser and Hermes 1962; Pieters et al. 1983; Brash et al. 1991; Fig. 2). The Middle Miocene saw a significant increase in the rate of relative sea-level rise, driven by regional subsidence (Visser and Hermes 1962; Satyana 2003; Wilson 2006). During this time, carbonate platforms failed to keep pace with the rate of relative sea-level rise, attributed to the onset of extensional tectonics (Visser and Hermes 1962), and drowned.

Extension was driven by the continued convergence of the Pacific and Australian plates whereby the Pacific plate converges WSW at $\sim 248^{\circ}$ relative to the Australian plate (Wallace et al. 2004; Cloos et al. 2005; Fig. 1). Paleomagnetic measurements from the Bird's Head show little evidence for rotation away from this azimuth with respect to Australia throughout the Neogene (Klootwijk et al. 1986; McCaffrey and Abers 1991). Convergence about this azimuth during the early Neogene directed maximum compressive stress towards the SW and minimum compressive stresses directed NW-SE. Similar NW-SE-directed extension is described in Seram (Fig. 1) as occurring at the same time as the Bird's Head at approximately $15 \mathrm{Ma}$ (Pownall et al. 2013, 2014). In the Bird's Head, minimum compressive stress propagating NW-SE caused the formation of several NE-SW-striking extensional basins. On the northern New Guinea margin, these basins developed in the Niengo Basement Platform (Fig. 1), which formed as a series of horsts and grabens that developed due to the oblique motion between the Australian and Pacific plates (Williams and Amiruddin 1983; McAdoo and Haebig 1999).

The tilted half-grabens and other extensional structures in the Niengo Basement Platform area strike NE-SW (Fig. 1). Examples of these include the NE-SW-trending Sorendidori Fault and Numfoor Ridge (Fig. 1). The Sorendidori Fault is an oblique normal fault that separates and downthrows younger Neogene sediments of the island of Biak to the SE from Early to Middle Miocene carbonates of the island of Supiori to the NW (Fig. 1). Extension is interpreted to have ceased by the end of the Miocene where Pliocene-Pleistocene carbonates are draped undisturbed across extensional tilted blocks.

By the end of the Miocene, the Sorong Fault Zone ceased to be a major feature. Pliocene strata that unconformably cover the eastern end of the Sorong Fault Zone in the northern Bird's Head are not broken by any active strike-slip faults (Hamilton 1979) and it is now considered to be inactive (Watkinson and Hall 2016). However, during the Pliocene, convergence between the Australian and Pacific plates was accommodated by other strike-slip faults developed in the Bird's Head region. The Ransiki Fault, originally formed as a collisional suture, was reactivated as a zone of dextral strike-slip with a recent extensional component (e.g., Watkinson and Hall 2016). The Yapen and Biak Fault Zones (Fig. 1) also became major features. The Biak Fault Zone is a series of segmented, parallel, NW-SE-trending strike-slip faults that form the linear coastline of Supiori's peninsula, linking with the linear coast of southwest Biak (Fig. 1). These faults also form clearly expressed lineaments on the seafloor that can be observed in multibeam bathymetric data (Fig. 1). The Biak Fault Zone is shown to be a young feature by incising the youngest Pliocene sequences and recent sedimentation within the Biak Basin is controlled by activity along the faults (Bertoni and Garcia 2012; Memmo et al. 2013). Recent seismicity along the Biak Fault Zone exhibits a distinct dextral slip component along the fault zone.

The Yapen Fault forms the E-W-trending linear coastline of the north coast of Yapen Island and a submarine ridge extending westward from Yapen to the eastern Bird's Head (Fig. 1). It separates the Woinoei Sorenia Strait in the north from a part of Cenderawasih Bay over $2000 \mathrm{~m}$ deep in the south. The Yapen Fault is a well-documented left-lateral structure. The fault strikes SE onshore to the east of the island of Yapen where it is termed the Jobi Fault system. The Jobi Fault in eastern Yapen (Fig. 1) has been shown to display left-lateral offset (Atmawinata and Ratman 1982; Dow and Hartono 1982; Atmawinata et al. 1989). The associated Randaway Fault system that cuts obliquely SE through the center of the island (Fig. 1) is proposed to have been active since the Pliocene or later, having incised the Ansus Conglomerate (Fig. 2), dated by foraminiferal assemblages to be of Pliocene age (Charlton 2010). This sub-recent movement of the Yapen Fault is supported by the sharp bathymetric expression of the submarine ridge on the seafloor (Fig. 1) and the occurrence of numerous sinistral strike-slip earthquakes along its course.

In the Bird's Neck, the Lengguru Fold and Thrust Belt (LFTB) forms the westward extension of the mountains of the Central Ranges (Fig. 1). The LFTB is stated to have formed in the last 7-8 Ma from the Tortonian (Bailly et al. 2011) based on ages of metamorphism from internal rock units within the LFTB. Their results suggested that a highpressure metamorphic event took place during the latest Tortonian to Messinian (7-8 Ma) followed by rapid exhumation associated with migmatization only 1 or 2 Ma after their burial. This rapid exhumation is able to produce highpressure metamorphic rocks in less than $5 \mathrm{Ma}$, validating fission-track ages of metamorphic units in New Guinea that suggest rapid uplift occurred in New Guinea since $10 \mathrm{Ma}$ and in many areas since $5 \mathrm{Ma}$ (Hill and Gleadow 1989). This uplift continued into the Pliocene, culminating with the formation of the regional 'intra-Pliocene unconformity' 
known from within the Salawati Basin to occur at approximately 4 Ma (Decker et al. 2009).

\section{Previously described drowning successions in the Bird's Head}

Strata that may represent drowning successions have been described previously in the Bird's Head, but were not recognized as such (e.g., Visser and Hermes 1962; Pieters et al. 1983; Gibson-Robinson and Soedirdja 1986; Brash et al. 1991; McAdoo and Haebig 1999). Examples include successions of limestones and/or siliciclastic sediments with alternating benthic and planktonic fossil assemblages recorded along the northern coast of New Guinea (e.g., Visser and Hermes 1962; Gibson-Robinson and Soedirdja 1986; McAdoo and Haebig 1999).

\section{North Irian Basin}

The North Irian Basin (also termed the 'Mamberamo' or 'North Coast' Basin) is located in the Mamberamo region of the Bird's Shoulder along the northern New Guinea margin (Fig. 1). This basin is described as a single large basin with interconnected, separate depocentres sharing a correlative fill (McAdoo and Haebig 1999). The North Irian Basin formed between structural highs of the Niengo Basement Platform, comprising ocean-floor or island arc volcanic and ultramafic material, since the Paleocene (McAdoo and Haebig 1999).

McAdoo and Haebig (1999) described continuous Cenozoic deposition within the North Irian Basin with the exception of a regional depositional hiatus in the Late Miocene. This hiatus is marked by a major unconformity, found at the base of the Mamberamo Formation and the top of the Makats Formation (Fig. 2, Column F), and traceable over large areas of the basin (Visser and Hermes 1962; McAdoo and Haebig 1999). We suggest that this may be a drowning unconformity as it separates shallow-water platform carbonate from overlying deep-water marl and pelagic carbonate. This facies change is contemporaneous with other such changes across New Guinea interpreted to record regional platform drowning and can be traced into the eastern Bird's Head (Fig. 2, Column C) and islands of Biak and Supiori (Fig. 2, Column D).

\section{Salawati and Bintuni Basins}

Many authors agree that the Salawati and Bintuni Basins (Fig. 1) are built on continental crust of either the northern promontory (Sula Spur) of the Australian plate (Redmond and Koesoemadinata 1976; Chevallier and Bordenave 1986; Gibson-Robinson and Soedirdja 1986; Phoa and Samuel 1986; Charlton 1996), or a small microcontinent comprising the Bird's Head (Pigram et al. 1982; Dow and Hartono 1982; Pigram and Panggabean 1984; Pigram and Davies 1987; Struckmeyer et al. 1993; Puntodewo et al. 1994; Hall 2002; Wilson 2006; Tikku et al. 2006).

The Bintuni Basin overlies a basement of NGLG that ceased deposition in the Middle Miocene (Pigram et al. 1982). It is interpreted to have formed as a fore-deep in the late Cenozoic (Chevallier and Bordenave 1986) when the former shallow-marine NGLG platform was rapidly deepened as a result of collision between the Bird's Head microcontinent with the Australian continent along a short-lived east-facing subduction zone (Pigram et al. 1982).

In the Salawati and Bintuni Basins, and in outcrop in the western Bird's Head, the Kais Limestone of the NGLG is overlain by marl and micritic limestone of the Klasafet and Klamogun Formations, both interpreted as pelagic strata (Visser and Hermes 1962; Fig. 2, Columns A and B). On depositionally topographic highs, the upper part of the Kais Limestone is overlain by the Sekau Formation (Visser and Hermes 1962; Koesoemadinata 1976; Pieters et al. 1983). This unit is described as comprising limestones with the same faunal composition as the Kais Limestone, interbedded with marl, clay, and argillaceous limestones occurring on topographically high coral reefs at the time of deposition (Visser and Hermes 1962). It is interpreted here that the interbedded sequences between the Kais Limestone and fully pelagic strata of the Klasafet and Klamogun Formations represent drowning successions. The drowning unconformity is therefore situated at the base of the Klasafet and Klamogun formations (Fig. 2).

In the Salawati Basin, the ' $U$ ' Interval overlies the Kais Limestone as a succession of interbedded limestone and siliciclastic strata. This heterolithic succession represents another gradual facies transition of shallow-water platform carbonates of the Kais Limestone to fully pelagic strata of the Klasafet and Klasaman Formations. The boundary between this heterolithic interval and wholly siliciclastic strata of the Upper Klasafet and Klasaman Formations is termed the ' $U$ ' Marker (Gibson-Robinson and Soedirdja 1986; Satyana 2003). The 'U' Marker is an easily recognized horizon in seismic and well logs (Valenta 1979; Gibson-Robinson and Soedirdja 1986) marking a sharp transition from mixed limestone and calcareous clays below to mainly clays above (GibsonRobinson and Soedirdja 1986). We interpret the 'U' Interval as a drowning succession and the ' $U$ ' Marker as a drowning unconformity within the Salawati Basin (e.g., Gold et al. 2014). 


\section{Materials and methods}

Fieldwork was undertaken in the eastern Bird's Head region in 2011 and 2013 during which heterolithic successions of carbonate strata were observed at several localities (Fig. 3). Heterolithic successions were observed at the top of the Maruni Limestone along the eastern coast of the Bird's Head, the Kais Limestone near the village of Anjai in the central Bird's Head (Fig. 3), and Napisendi Formation along the northern coasts of the islands of Biak and Supiori (Fig. 3). However, the best exposure occurs above the Maruni Limestone along the Anggrisi River (Sungai Anggrisi), south of the city of Manokwari (Fig. 3). Vertical facies variations within the heterolithic sections were measured and the sedimentological and paleontological features were recorded at each bed.

At each locality, a clear change in facies together with a faunal turnover from shallow-water benthic to pelagic planktonic foraminiferal assemblages was observed. A simple scheme, based on lithology and foraminiferal assemblage, was devised to record the spatio-temporal distribution of facies across the study area (Fig. 4). The facies scheme contained four categories: (1) shallow-water platform, (2) argillaceous platform, (3) periplatform, and (4) pelagic (Fig. 4). This scheme is based on carbonate rock fabrics, textures, and paleoenvironmental interpretations of foraminiferal assemblages from Bé and Tolderlund (1971), Bé (1977), Hallock and Glenn (1986), and BouDagher-Fadel (2008).

The Sungai Anggrisi section was determined to be representative of heterolithic successions in the eastern Bird's Head and was chosen for more detailed analysis. Fourteen localities along Sungai Anggrisi were visited (Fig. 5) and stratigraphic sections were measured, and sedimentological and paleontological features were recorded. Systematic sampling occurred at each facies change for detailed microfacies and biostratigraphic analyses. Thin-sections were prepared of the samples and stained with a mixture of Alizarin Red S and potassium ferricyanide (Dickson 1966) to aid in the identification of ferroan and non-ferroan phases of calcite. Thin-sections were then classified according to microfabrics and microfossil composition. During these detailed analyses, six distinct foraminiferal assemblages were identified within the facies scheme (Fig. 6). Data from all 14 localities along Sungai Anggrisi were collated to produce a composite log of the eastern Bird's Head heterolithic succession (Fig. 6).

Biostratigraphic data from outcrop samples collected from localities with a close field-relationship to the heterolithic successions depicted in Fig. 3 were used to display the full spatial distribution of facies belts across the field area. Gross depositional environment maps were produced of the field area during the early, middle, and late
Miocene, comprising 105 data points (Fig. 7). Biostratigraphic data from 15 public domain wells (Table 1) were also reviewed and identified a similar turnover of faunal assemblages and facies in areas to the west of the field area. Ages were assigned to well data and outcrop samples based on assemblages of planktonic and larger benthic foraminifera. Ranges of taxa were taken from Adams (1970), Iaccarino et al. (2007), and BouDagher-Fadel (2008) and were calibrated to the Indo-Pacific 'letter stages' (Adams 1970; BouDagher-Fadel 2008; Lunt 2013) and Wade et al. (2011) sub-tropical planktonic foraminiferal zones. Biozonation schemes used in this study are the Indo-Pacific 'letter stages' of Adams (1970), BouDagher-Fadel (2008), and Lunt (2013) for larger benthic foraminifera, and Wade et al. (2011) for sub-tropical planktonic foraminiferal zones. Sub-tropical planktonic foraminiferal zones were calibrated to Timescale Creator (version 6.1.2, http://www. tscreator.org) following the geological timescale of Gradstein et al. (2012).

\section{New outcrop evidence for platform drowning in the Bird's Head}

We define the section along Sungai Anggrisi (Figs. 3b-c, $5,6)$ as a stratotype for carbonate platform drowning in the Bird's Head. This stratigraphic section serves as an analogue to similar successions observed in the subsurface of offshore basins to the west of New Guinea. The heterolithic succession at Sungai Anggrisi is approximately $20 \mathrm{~m}$ thick and displays all four facies defined in Fig. 4. Six unique foraminiferal assemblages are identified within the succession that reflect the faunal turnover from shallow-water carbonate platform deposition to wholly pelagic strata through time (Fig. 6).

\section{Shallow-water platform facies}

The basal unit of the Sungai Anggrisi succession comprises reefal platform carbonate of the Maruni Limestone (Figs. 3b, 6). This unit is well bedded, with planar beds dipping $250 / 10^{\circ} \mathrm{NW}$, comprising white-colored and wellcemented fossiliferous limestone (Figs. 3b, 6). The limestone is dominated by larger benthic foraminifera; however, bivalve fragments, corals, and the rhodophyte Lithophyllum spp. are also present. Through petrographic analysis, it is classified as a mud-lean packstone comprising $\sim 70 \%$ bioclasts, $\sim 20 \%$ non-ferroan spar cement, and $\sim 10 \%$ matrix. Larger benthic foraminifera within this limestone include Eulepidina spp. (including E. badjirraensis), Lepidocyclina (Nephrolepidina) brouweri, Lepidocyclina (N.) oneatensis, Lepidocyclina (N.) sumatrensis, Miogypsina kotoi, Miogypsina tani, Miogypsinodella primitiva, Miogypsinoides spp. (including $M$. 

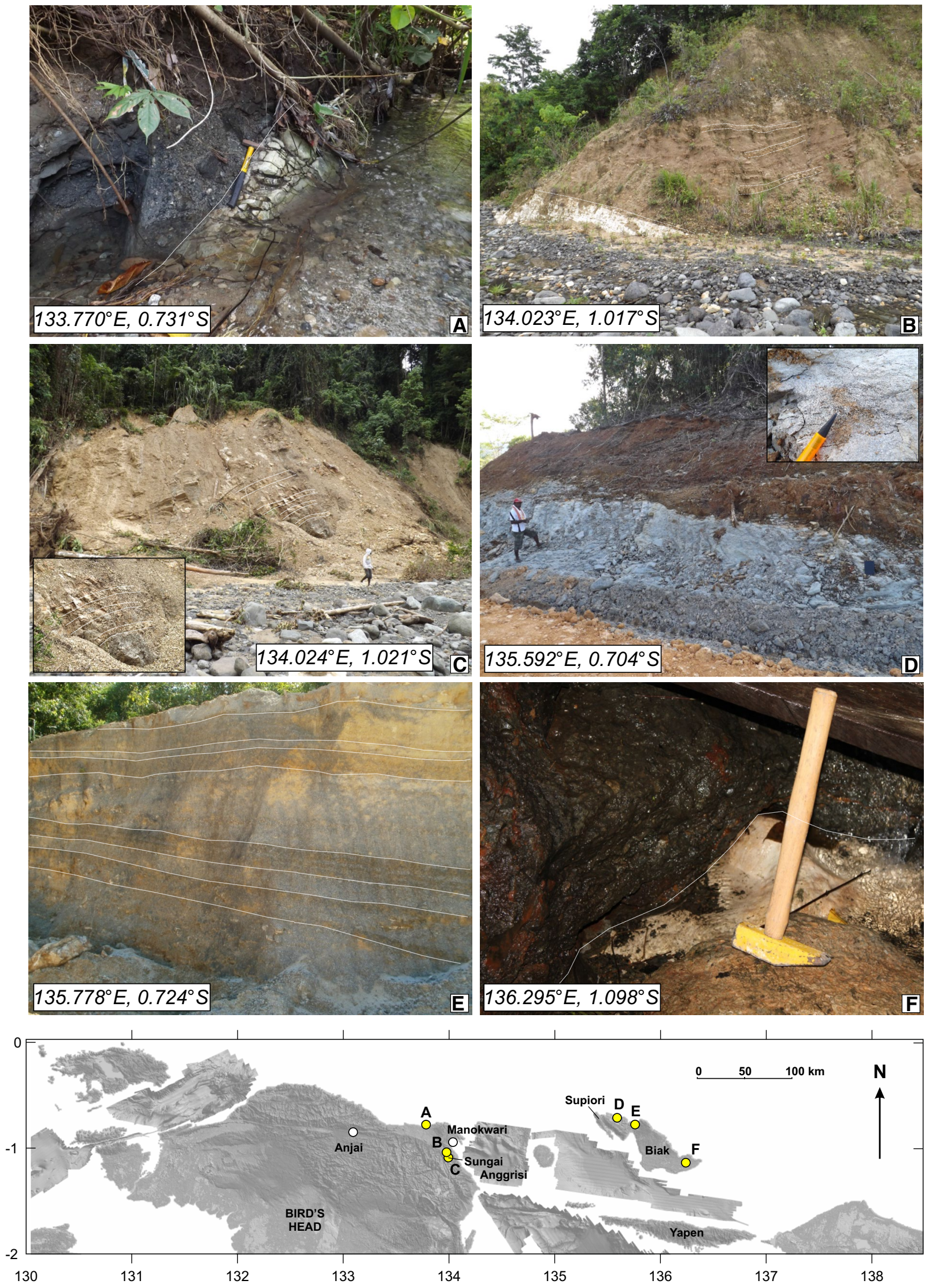
\Fig. 3 Field photos of drowning successions and drowning unconformities across the northern Bird's Head. The drowning succession is marked by a sharp change in facies from platform carbonates beneath and dark shales or heterolithic grey marl and brown packstone above. a Befoor Formation unconformably overlies the Maruni Limestone in the north-eastern corner of the Bird's Head, north of Manokwari. b Drowning succession at the top of the Maruni Limestone along the river Sungai Anggrisi, south of Manokwari. c Heterolithic drowning succession beds observed farther along Sungai Anggrisi. d Deep-water facies rocks containing abundant planktonic foraminifera within the Napisendi Formation on the northern coast of Supiori. e Heterolithic grey marl and better indurated brown packstone within the Napisendi Formation on the island of Biak. $\mathbf{f}$ Underlying platform limestone of the Napisendi Formation beneath dark grey shales in the south-east of the island of Biak

dehaarti and M. bantamensis), and Spiroclypeus tidoenganensis. These taxa represent foraminiferal Assemblage 1 and suggest an Early Miocene, late Aquitanian (middle Te5 letter stage, equivalent to sub-tropical zone M2, 21.12-19.3 Ma) to middle Burdigalian age (upper Te5 letter stage, equivalent to sub-tropical zone M3, 19.3-17.54 Ma) for the deposition of this limestone (Adams 1970; BouDagher-Fadel 2008). The microfossil assemblage, containing reef-loving organisms such as lepidocyclinid and miogypsinid foraminifera, and red algae that favor the seaward side of reef crests, together with the relatively large amount of early diagenetic marine spar and fragmentation, indicate deposition within a relatively high-energy reef-front environment (Hallock and Glenn 1986). The shallow-water platform facies was observed at three localities along Sungai Anggrisi (Figs. 5, 6).

\section{Argillaceous platform facies}

The planar bedded white limestone unit is paraconformably overlain by alternating irregular beds of grey marl and brown packstone in a succession approximately $20 \mathrm{~m}$ thick (Figs. 3b, 6). This heterolithic succession is equivalent to the Sekau Formation of the western Bird's Head (Fig. 2). The white limestone has a sharp planar contact with the overlying heterolithic succession parallel to bedding. Carbonate interbeds within the succession comprise brown, well-indurated, argillaceous mud-lean packstone and grainstone that contain abundant larger benthic and planktonic foraminifera, bivalve fragments, rhodophyte red algae, and ferroan cement (Fig. 4). Trypanites ichnofacies vertical burrows are observed along bed boundaries in contact with the overlying grey marl. Biostratigraphic analyses of the lower brown packstone interbeds contain a larger benthic foraminiferal assemblage including Lepidocyclina (Nephrolepidina) brouweri, $L .(N$.) nephrolepidinoides, $L$. (N.) stratifera, $L$. (N.) verbeeki, Miogypsina cushmani, M. intermedia and Miogypsinoides indica. This assemblage suggests an Early to Middle Miocene, Burdigalian to early Langhian (lower Tf1-upper Te5 letter stages, equivalent to sub-tropical zones
M3-M5, 19.3-15.1 Ma) age for these units (Adams 1970; BouDagher-Fadel 2008). The foraminiferal assemblage in these interbeds represent Assemblage 3 and indicate an inner neritic depositional setting. The argillaceous platform facies was observed at seven localities (Figs. 5, 6). Fossils identified from within this facies are interpreted to have been deposited in situ as bioclasts display no evidence for transportation (e.g., through abrasion, fragmentation, or as intraclasts). The presence of Trypanites ichnofacies borings also indicate that these carbonates were deposited in situ and the platform top may have formed hard grounds.

\section{Periplatform facies}

The uppermost packstone beds contain an increasing abundance of large, flat, rotaliina foraminifera, which include Cycloclypeus indopacificus, Katacycloclypeus annulatus, Lepidocyclina (Nephrolepidina) ferreroi, L. (N.) inflata, $L$ (N.) martini, Miogypsina antillea, M. kotoi, M. regularia, Planostegina spp. and Operculina spp. These foraminifera represent Assemblage 5 and suggest a Middle Miocene, middle Langhian to latest Serravallian (upper Tf1-Tf3 letter stages, equivalent to sub-tropical zones M6-10, 15.1-11.63 Ma) age (Adams 1970; BouDagher-Fadel 2008). The abundance of large, platy benthic foraminifera indicates deposition in relatively moderate water depths between 20 and $50 \mathrm{~m}$ in platform slope or periplatform environments (Hallock and Glenn 1986). The latest Serravallian age assigned to the uppermost brown packstone bed of the heterolithic succession is based on the last observed occurrences of $K$. annulatus and $C$. indopacificus, which are zonal markers for the end of Indo-Pacific letter stages Tf 2 and Tf3, respectively (BouDagher-Fadel 2008). The $\mathrm{Tf} 3 / \mathrm{Tg}$ boundary (11.63 Ma) of the Indo-Pacific Letter Stages is denoted by a significant faunal turnover in larger benthic foraminifera at the end of the Serravallian (Adams 1970; BouDagher-Fadel 2008). However, the faunal turnover at the Tf3/Tg boundary in New Guinea is denoted by complete facies change in planktonic foraminifera replacing shallow-water taxa, rather than a change in composition of shallow benthic assemblage. The uppermost periplatform facies was observed at three localities (Figs. 5, 6).

\section{Pelagic facies}

The argillaceous platform and periplatform facies are interbedded with grey marl within the heterolithic succession. Petrographic analysis of the marl shows them to be packstone comprising $~ 90 \%$ planktonic foraminifera and $\sim 10 \%$ micrite matrix. Planktonic foraminifera within marl of the lower half of the heterolithic succession include Catapsydrax dissimilis, D. altispira, D. baroemoensis, Globigerina 


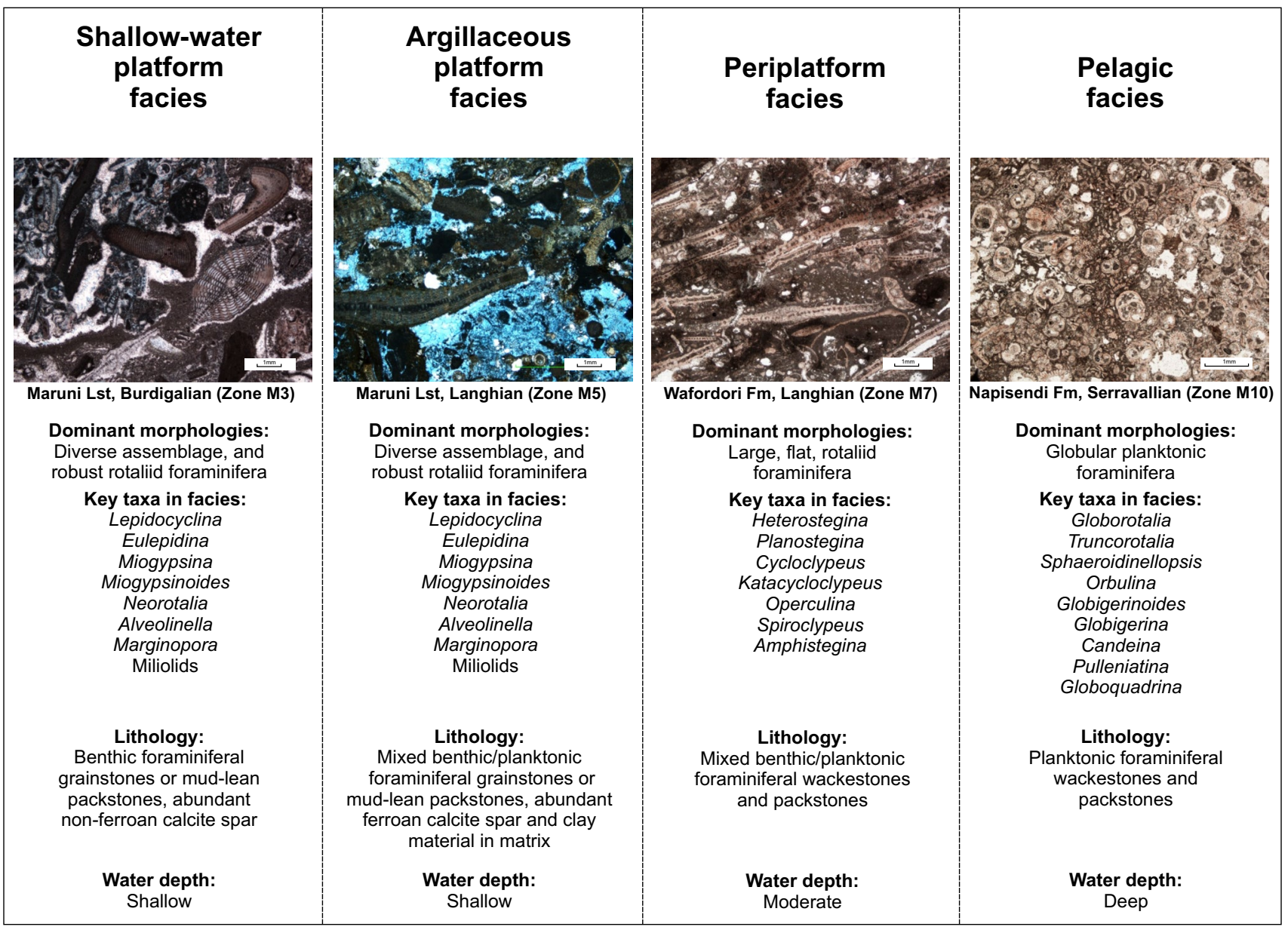

Fig. 4 Samples analyzed for petrography were grouped into four facies based on microfacies and faunal composition. 1 Shallow-water platform facies contain a diverse assemblage of organisms including robust rotaliid foraminifera often within grainstone or mud-lean packstone. 2 Argillaceous platform facies contain similar faunal composition to the shallow-water platform facies with the inclusion of significant ferroan calcite cement. 3 Periplatform facies comprise packstone containing large, flat, rotaliid foraminifera. 4 Pelagic facies comprise packstone and wackestone that contain abundant planktonic foraminifera. Microfossil paleoenvironmental and bathymetric interpretations were made using Bé and Tolderlund (1971), Bé (1977), Hallock and Glenn (1986), and BouDagher-Fadel (2008)
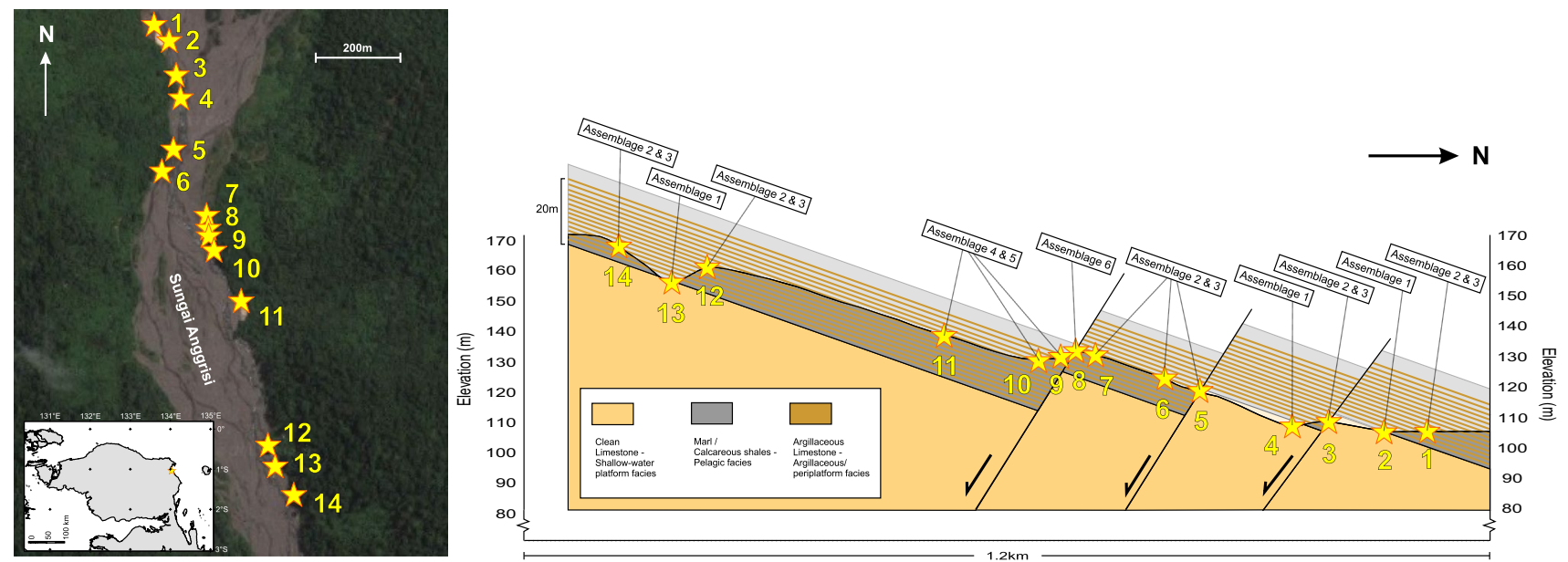

Fig. 5 Stratigraphic and structural cross section depicting the locations, foraminiferal assemblages, and facies encountered at 14 locations along the drowning succession observed at Sungai Anggrisi, eastern Bird's Head. Satellite image credit: Google Earth (Map data: Google, DigitalGlobe) 
occlusa, Ga. praebulloides, Globigerinoides altiaperturus, Gdes. obliquus, Gdes. quadrilobatus, Gdes. subquadratus, Gdes. trilobus, G. dehiscens, G. woodi and Praeorbulina glomerosa. These taxa represent foraminiferal Assemblage 2, which suggest an Early Miocene, Burdigalian (sub-tropical zone M3, 19.3-17.54 Ma) to Middle Miocene, early Langhian (sub-tropical zone M5, 16.38-15.1 Ma) age for this unit (Iaccarino et al. 2007; BouDagher-Fadel 2015). Globular planktonic foraminifera are common in the basal grey marl of the succession and are indicative of 'moderate' water depths between 50 and $100 \mathrm{~m}$ (Bé and Tolderlund 1971; Bé 1977). The large number of globular planktonic foraminifera, with a planktonic:benthic ratio greater than 100:1, and micrite mud in this sample, indicate it was deposited as a pelagic limestone in a middle neritic environment. The lower pelagic facies was observed at seven localities (Figs. 5, 6).

The upper part of the heterolithic succession contains different assemblages of interbedded benthic and planktonic foraminifera. The upper grey marl contains the planktonic foraminifera $D$. altispira, $D$. baroemoensis, D. globosa, $D$. quadrata, D. venezuelana, Globigerina decoraperta, Ga. eamesi, Ga. occlusa, Ga. praebulloides, Globigerinella praesiphonifera, Globigerinoides quadrilobatus, Gdes. subquadratus, Gdes. trilobus, G. dehiscens, Globorotalia conoidea, Grot. menardii, Grot. miozea, Grot. peripheroronda, Grot. praemenardii, Grot. scitula, Globoturborotalita woodi, Orbulina bilobata, O. suturalis, O. universa and Sphaeroidinellopsis subdehiscens. These taxa represent foraminiferal Assemblage 4 and suggest a Middle Miocene, middle Langhian (sub-tropical zone M6, 15.1-14.24 Ma) to latest Serravallian (sub-tropical zone M10, 11.79-11.63 Ma) age for this marl (Iaccarino et al. 2007; BouDagher-Fadel 2015). An increasing abundance of carinate planktonic foraminifera is observed up-section and indicates increasing water depths in excess of $100 \mathrm{~m}$ (Bé and Tolderlund 1971; Bé 1977). The upper pelagic facies was observed at three localities (Figs. 5, 6).

The heterolithic succession above the Maruni Limestone passes upwards to Befoor Formation siliciclastic strata (Figs. 2, 6). The Befoor Formation is dated to range from the Late Miocene, Tortonian, to Pliocene, Zanclean (sub-tropical zones M11-PL3, 11.63-3.59 Ma). However, along Sungai Anggrisi, only the lower Befoor Formation is observed, representing the Tortonian to Messinian (sub-tropical zones M11-M14, 11.63-5.72 Ma) based on the presence of the planktonic foraminifera G. dehiscens, Globorotalia menardii, Pulleniatina primalis, Globigerinoides quadrilobatus, Gdes. trilobus, N. acostaensis, and S. subdehiscens (Iaccarino et al. 2007; BouDagher-Fadel 2015). These taxa represent Assemblage 6 and are observed at a single locality along Sungai Anggrisi (Figs. 5, 6). This assemblage is recorded within a continuous succession of pelagic facies strata and an absence of interbeds of shallower-water carbonates. The Befoor Formation is observed as an uninterrupted succession of wholly pelagic facies strata several tens of meters thick where it is widespread northwest of Manokwari, until carbonate deposition resumes once more in the Zanclean (Fig. 2).

\section{Interpretation of the Sungai Anggrisi drowning succession}

Heterolithic beds overlying the white reefal limestone along Sungai Anggrisi are interpreted here as a drowning succession, formed during approximately 7.5 My of Burdigalian-Serravallian carbonate platform drowning. Heterolithic successions were interpreted as drowning strata based on sedimentological and stratigraphic evidence marked by significant facies and faunal changes (e.g., Masse and Fenerci-Masse 2011). The initiation of platform drowning is interpreted to have occurred during sub-tropical planktonic foraminiferal zone M3 (19.3-17.54 Ma) due to the transition from shallow-water platform to argillaceous platform and pelagic facies likely occurring some time within this zone (Fig. 6). The faunal turnover observed between the periplatform and pelagic facies at the $\mathrm{Tf} 3 / \mathrm{Tg}$ boundary $(11.63 \mathrm{Ma})$ is interpreted to mark the age of completion of carbonate platform drowning as it represents the last bed of periplatform facies strata underlying wholly deep-water strata of uninterrupted pelagic facies (Fig. 6). The drowning unconformity therefore is situated above the uppermost bed containing Assemblage 5 taxa (Fig. 6) and is interpreted to correlate to the unconformity described by McAdoo and Haebig (1999) within the North Irian Basin, the ' $U$ ' Marker within the Salawati and Bintuni basins, and uppermost limestone unit of the Sekau Formation in the western Bird's Head. In the eastern Bird's Head, only c. $20 \mathrm{~m}$ of the heterolithic succession is exposed, consistent with descriptions of the 30-50-m-thick Sekau Member of the western Bird's Head (Visser and Hermes 1962; Pieters et al. 1983). However, this is considerably less than the c. 200-m ' $U$ ' Interval found in the southern Salawati Basin.

The Early Miocene units of the NGLG, including the Maruni and Kais Limestones, are interpreted to represent typical carbonate platform deposits (e.g., Hallock and Schlager 1986). The Maruni Limestone is interpreted to have been deposited as part of a rimmed platform containing proximal back-reefs, passing basinward to fringing reefs and periplatform slope facies. The basal white Maruni Limestone of the Sungai Anggrisi succession represents healthy platform growth, deposited with high average surface water temperatures, high water transparency, and low levels of available nutrients (e.g., Föllmi et al. 1994). Low nutrient levels (oligotrophy) are indicated by the presence of large benthic foraminifera and absence of silt and coarser siliciclastic grains, indicating low levels of terrestrial runoff and therefore nutrient supply (Hallock 1988; Weissert 1989, 1990; Föllmi et al. 1994).

Throughout the Miocene, carbonate production rates were reduced in the Bird's Head as denudation of land areas 


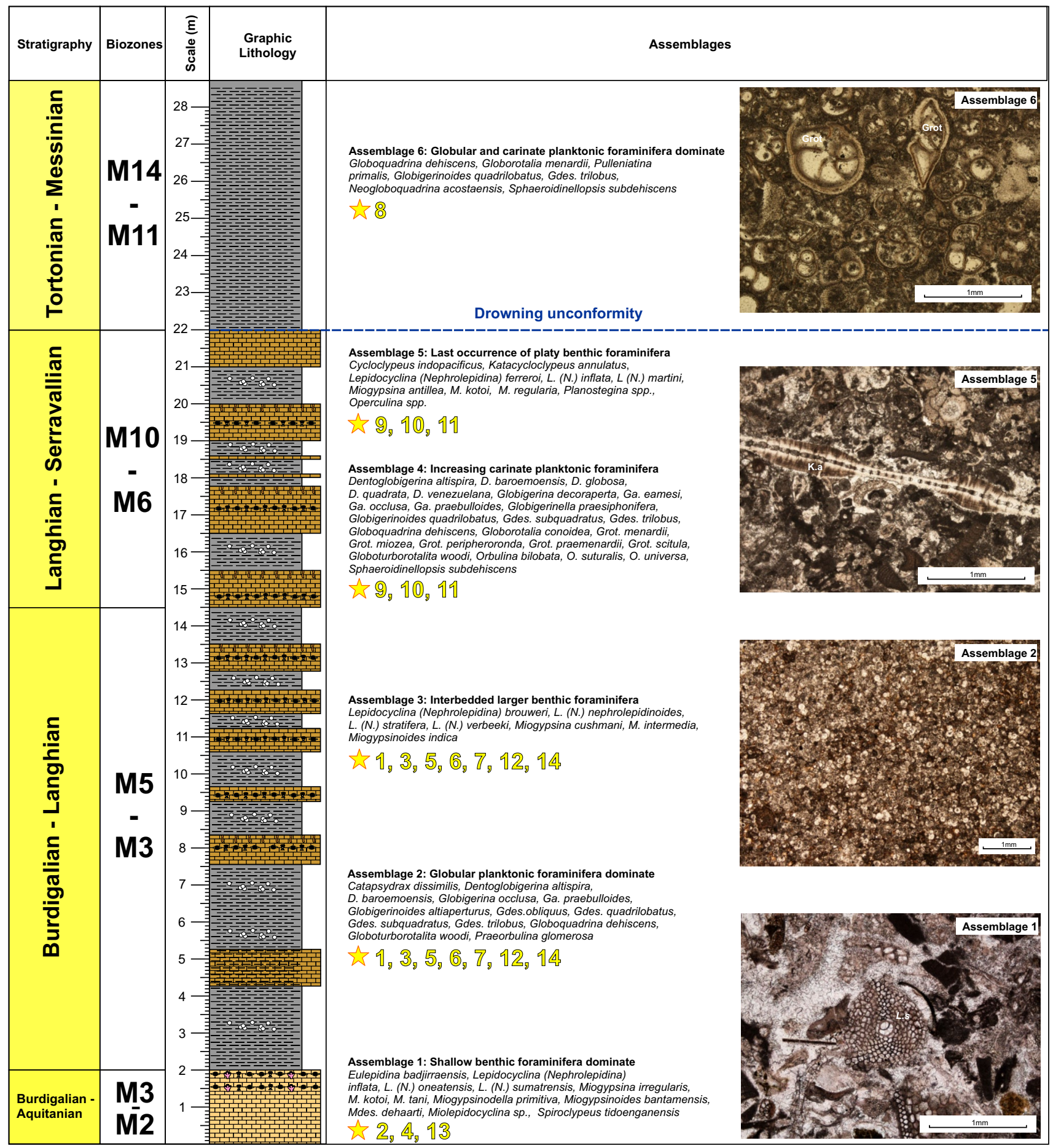

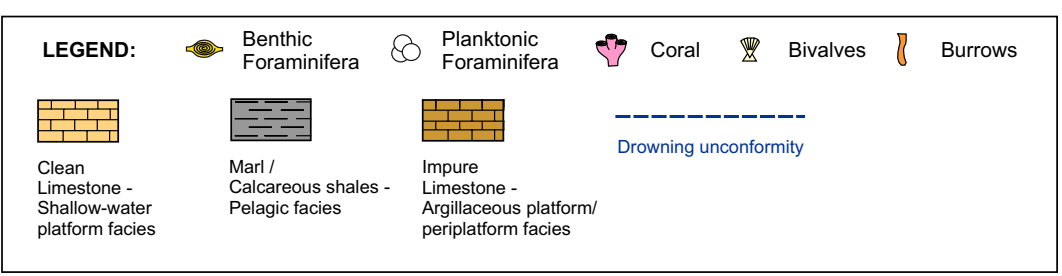


4Fig. 6 Composite sedimentary log based on field data collected at 14 localities visited at the drowning succession exposed along Sungai Anggrisi. The drowning succession deepens upwards with increasing numbers of globular and carinate planktonic foraminifera replacing typical reefal shallow benthic foraminifera and moderate-water-depth larger platy foraminifera. The uppermost periplatform facies bed contains specimens of Katacycloclypeus annulatus (K.a) in the microfossil assemblage, indicating a Serravallian age to the completion of the drowning process along Sungai Anggrisi. Modified from Gold et al. (2014)

increased the amount of terrigenous material shed into offshore areas (e.g., Wilson 2002). It is therefore interpreted that minor siliciclastic grains and iron within Fe-rich calcite cements in the argillaceous platform facies was sourced by terrestrial runoff. Iron was transported as particles of iron oxides from surrounding muddy, clay-rich sediment or adsorbed on to clays. The presence of Fe-enrichments in drowning and post-drowning sediments are often related to a primary higher nutrient content in the water column and a change from oligotrophic to meso- or eutrophic conditions (Zempolich 1993; Föllmi et al. 1994; Drzewiecki and Simo 1997; Blomeier and Reijmer 1999).

Carbonate accumulation rates are inversely related to nutrient availability at levels typically found in modern, low-latitude oceans (Hallock and Schlager 1986). One such nutrient involved in the primary productivity of oceans is iron. The link between increased iron and increased phytoplankton activity in the oceans is well established (Martin and Fitzwater 1988; Walsh and Steidinger 2001; Sellner et al. 2003; Winckler et al. 2008; Costa et al. 2016). The positive relationship between increasing amounts of iron and high phytoplankton growth rates occurs due to the role iron plays in photosynthesis, where iron-sulfur proteins, termed 'ferredoxins', mediate electron transfer in the metabolic reactions of photosynthesis (Geider and La Roche 1994). The increased amount of iron, and therefore phytoplankton, acted to reduce levels of transparency in the water column above the Maruni Limestone platform as conditions changed from that of oligotrophy to mesotrophy. Hallock and Schlager (1986) suggested that a reef cannot recover if submerged below $25 \%$ of surface light levels. This equates to only several meters or tens of meters of submergence required to drown present-day reefs in Aqaba, the Florida Keys, Hawaii, and Barbados (Hallock and Schlager 1986). The increasing abundance of carinate planktonic foraminifera replacing shallow-water benthos observed within drowning successions of the Bird's Head indicate an increase in water depths to at least $100 \mathrm{~m}$. This is more than sufficient to terminate carbonate production in waters where transparency is low. Burgess and Hovius (1998) demonstrated that where rates of fluvial discharge are high, such as areas of intense tropical denudation, many modern deltas are able to prograde during marine transgressions and times of high relative sea-level. This scenario explains how iron was introduced into the depositional environment through terrestrial run-off while water depths began to increase above the Maruni Limestone platform.

Environmental preferences of organisms observed within foraminiferal Assemblage 1 suggest that water depths locally were no greater than $20 \mathrm{~m}$ during deposition of the reefal Maruni Limestone at the initiation of the drowning process during the middle Burdigalian. The increasing abundance of carinate planktonic foraminifera up-section indicates that water depths increased to greater than $100 \mathrm{~m}$ (e.g., Bé and Tolderlund 1971; Bé 1977) by the Tortonian, a duration of approximately 7.5 My. An increase in water depth of at least $75 \mathrm{~m}$ in approximately 7.5 My recorded from the entire Sungai Anggrisi succession equates to a rate of regional relative sea-level rise of approximately $10 \mathrm{~m} / \mathrm{My}$. The lowest accumulation rates for prograding carbonates are reported as 30 m/My (Schlager 1981; Handford and Loucks 1993; Wissler et al. 2003), therefore a long-term rise in relative sea-level of $10 \mathrm{~m} / \mathrm{My}$ should not have been sufficient to outpace the rate of carbonate accumulation. This observation supports the 'drowning paradox' of Schlager (1981). However, Kim et al. (2012) demonstrated that the drowning paradox can be overcome if accumulation rates at the initiation of drowning are lower than the rate of relative sea-level rise. Evidence for mesotrophy in the carbonate production factory observed in the Sungai Anggrisi drowning succession may be one reason for initial carbonate accumulation rates to be low at this location. This may have been further exaggerated by the slow response time of benthic organisms of the periplatform and argillaceous platform facies to re-establish as relative sea-level rise continued to progress leading to drowning of the Maruni Limestone platform. The interpretation therefore is that a combination of relative sealevel rise and environmental deterioration is responsible for platform drowning in the Bird's Head.

The already-foundering Maruni Limestone platform top under elevated trophic conditions may have finally succumbed to drowning during shorter, more rapid pulses of relative sea-level rise (e.g., Hallock and Schlager 1986). Incursions of pelagic facies over argillaceous platform and periplatform facies limestones are interpreted here as catch-up and short-term keep-up deposition (as defined in Kim et al. 2012) when drowning during longer-term relative sea-level rise was interrupted by high-frequency sea-level falls of approximately 20-30 m during the middle Miocene (Miller et al. 2005; Snedden and Liu 2010; Fig. 2). The amplitude of these oscillations was enough to shift the deposition of periplatform and pelagic facies up and down the platform slope, depositing the relatively shallow-water facies during intervening troughs in the shortterm global sea-level trend (Fig. 2). The sharp increase in 
Fig. 7 Gross depositional environment maps depicting position of migrating belts of shallow-water carbonate platform, argillaceous/periplatform, and pelagic facies in the Early, Middle and Late Miocene.

Deeper-water facies encroach causing shallower-water areas to backstep to the north through time. Data points correspond to outcrop samples only

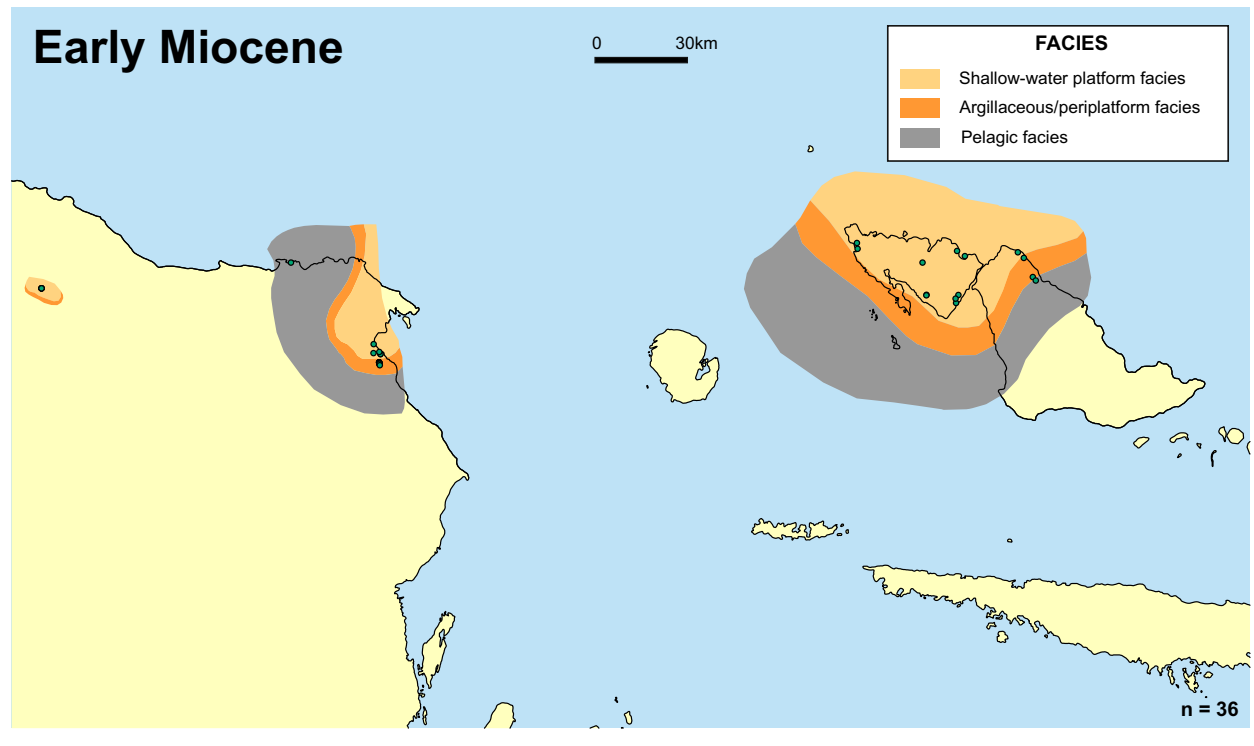

\section{Middle Miocene}

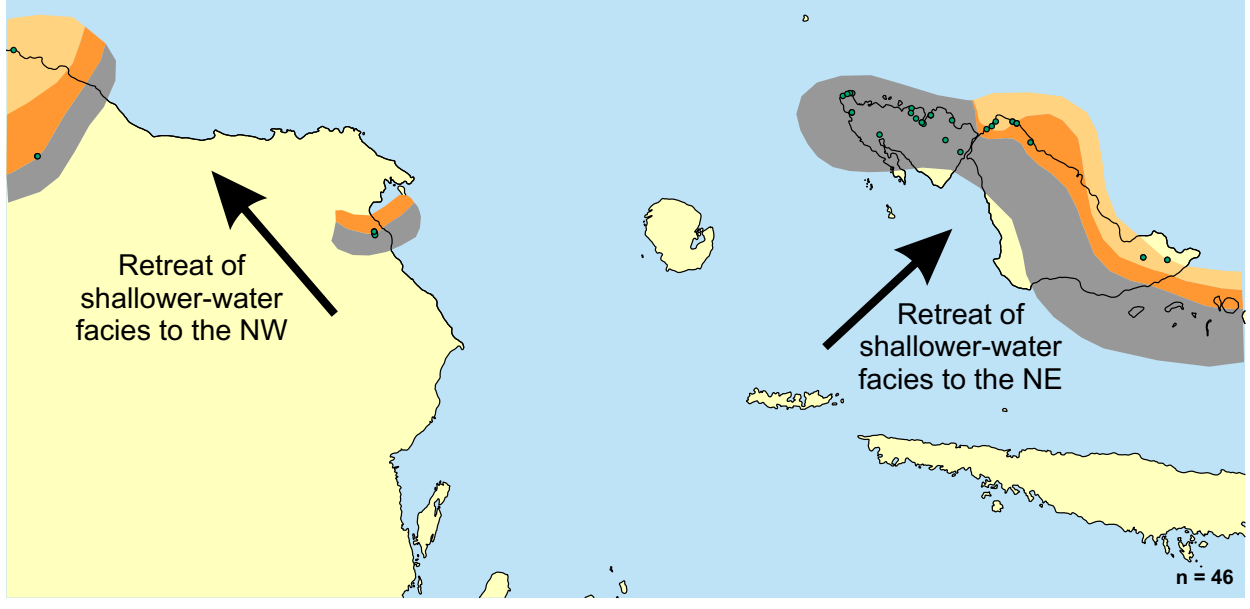

\section{Late Miocene}

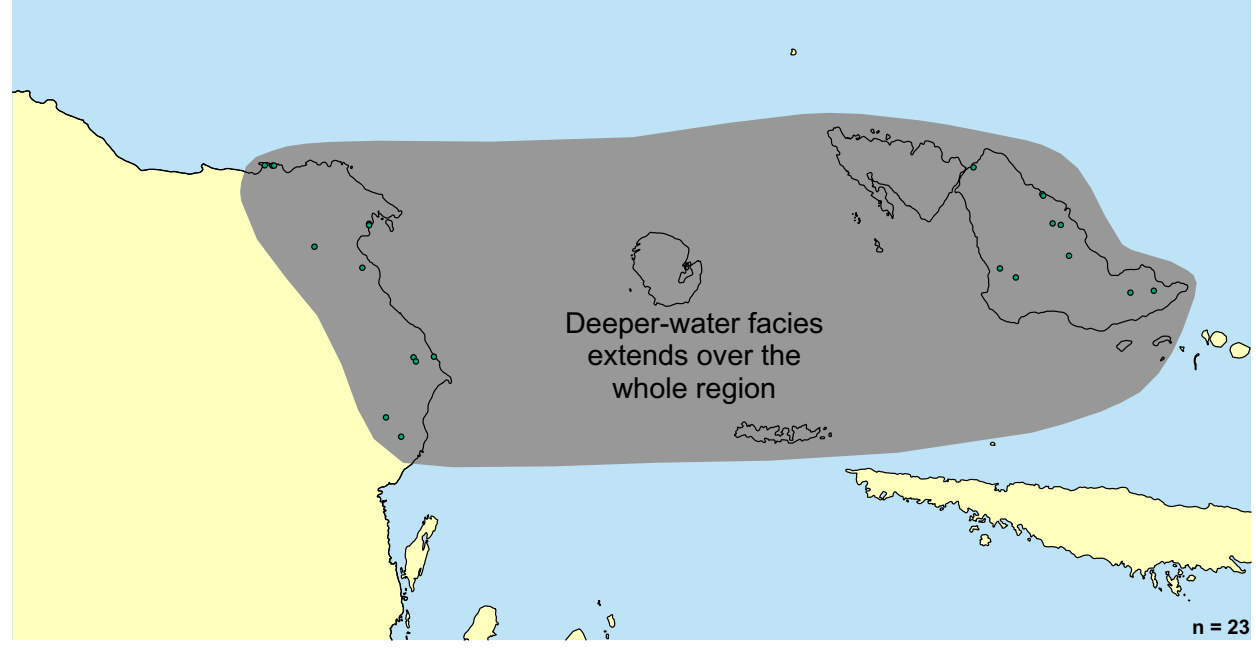


Table 1 References for public domain wells used in this study

\begin{tabular}{ll}
\hline Well & References \\
\hline Agung-1 & Fraser et al. (1993), Pairault et al. (2003) \\
ASA-1X & Darman and Sidi (2000) \\
Gunung-1 & Fraser et al. (1993), Pairault et al. (2003) \\
Klalin-1 & Livingstone et al. (1992) \\
Monie south-1 & Pigram et al. (1982) \\
Roabiba-1 & Fraser et al. (1993) \\
Sago-1 & Chevallier and Bordenave (1986) \\
Tarof-2 & Fraser et al. (1993) \\
TBA-1X & Livingstone et al. (1992) \\
TBA-2X & Livingstone et al. (1992) \\
TBE-1X & Koesoemadinata (1976), Chevallier and Bordenave \\
& (1986), Dolan and Hermany (1988), Fraser et al. \\
& (1993) \\
TBH-1X & Livingstone et al. (1992) \\
TBM-1X & Livingstone et al. (1992) \\
TBO-1X & Livingstone et al. (1992) \\
West Salawati & Satyana (2003) \\
\hline
\end{tabular}

the short-term global sea-level trend from approximately $20 \mathrm{~m}$ above present-day sea-level at the end of the Serravallian, to approximately $80 \mathrm{~m}$ above present-day sea-level at the Tor1 MFS, suggests a sudden sea-level rise of $60 \mathrm{~m}$ in 1 My (Fig. 2). This drastic increase in the rate of shortterm sea-level rise may have outpaced rates of carbonate production on the Maruni Limestone platform, resulting in the termination of keep-up deposition and formation of the drowning unconformity by the end of the Middle Miocene. By deposition of the Befoor Formation in the Tortonian, water depths were high enough that carbonate deposition on the platform was unable to re-establish and it was draped by the deep-water sediments that overlie the drowning unconformity.

The heterolithic succession between the Maruni Limestone and Befoor Formation may represent an easterly lateral equivalent to the Sekau Formation (Fig. 2). Several scenarios have been suggested for the deposition of the Sekau Formation. These include struggling reef growth in mud-polluted waters and limestone interbeds within the heterolithic succession representing fore-reef deposits encroached by relatively deeper-water marls (Visser and Hermes 1962; Pieters et al. 1983). Along Sungai Anggrisi both scenarios are shown to be true. Deposition in mudpolluted waters is indicated by the argillaceous platform facies, and encroachment of deeper-water sediments over a shallow-water platform is indicated by the periplatform and pelagic facies.

Through a reduction in carbonate accumulation rates by excess nutrients, outpaced by the rate of relative sea-level rise, transgression of pelagic strata occurred across the top of the Maruni Limestone platform. This is clearly shown in the gross depositional environment maps of Miocene age samples and outcrops from the eastern Bird's Head and islands of Biak and Supiori (Fig. 7). These delineate the shift in relative position of the migrating facies belts throughout the Miocene. The maps show the retreat of the shallow-water facies belts towards the north from the beginning to end of the Miocene (Fig. 7). The shallow-water carbonate platform facies (Fig. 4) is widespread across much of the Bird's Head during the Early Miocene (Fig. 7). During the Middle to Late Miocene, a faunal turnover of shallow-water benthic foraminiferal assemblages to deeper-water planktonic foraminiferal assemblages is observed as shallow-water facies are replaced by periplatform, platform, and pelagic facies (Fig. 4) across the study area (Fig. 7).

\section{Evidence for drowning in New Guinea from well data}

Further evidence for carbonate platform drowning was identified during review of biostratigraphic and wireline$\log$ data from 15 public domain wells (Table 1). These wells are located within the known hydrocarbon producing Salawati and Bintuni Basins, and Arafura Sea (Fig. 1). The closest well to the outcrop analogues described in this paper is approximately $200 \mathrm{~km}$ to the west. However, the Kais Limestone and overlying Sekau, Klasafet and Klasaman formations are widely distributed in outcrop between the data points of this study, implying that carbonate platform drowning occurred over a large area during the Middle to Late Miocene.

Biostratigraphic data from 15 wells in western New Guinea record a turnover in fauna and facies of open-marine assemblages of planktonic foraminifera replacing assemblages of shallower-water benthic foraminifera (Fig. 8). The termination of stable carbonate platform growth of the NGLG is recorded in wells Agung-1, Klalin-1, Sago-1, and TBE-1X to occur during the early Langhian (upper Te5 letter stage, equivalent to sub-tropical zone M5, 16.38-15.1 Ma; Fig. 8). The shutdown of stable carbonate platform growth is often denoted by the last occurrences, base to top, of 'reefal' organisms such as corals and sponges, and typical shallow-water benthic foraminifera including lepidocyclinids, miogypsinids, and miliolids (Fig. 8). Several wells, Monie South-1, Roabiba-1, and Sago-1, record observable heterolithic successions of planktonic foraminiferal calcareous shales and marls interbedded with shallow-water benthic foraminiferal limestones. These successions were deposited between the middle Langhian and latest Serravallian (M6-M10, 15.1-11.63 Ma), marking the inception and completion of the drowning process (Fig. 8). The completion of 


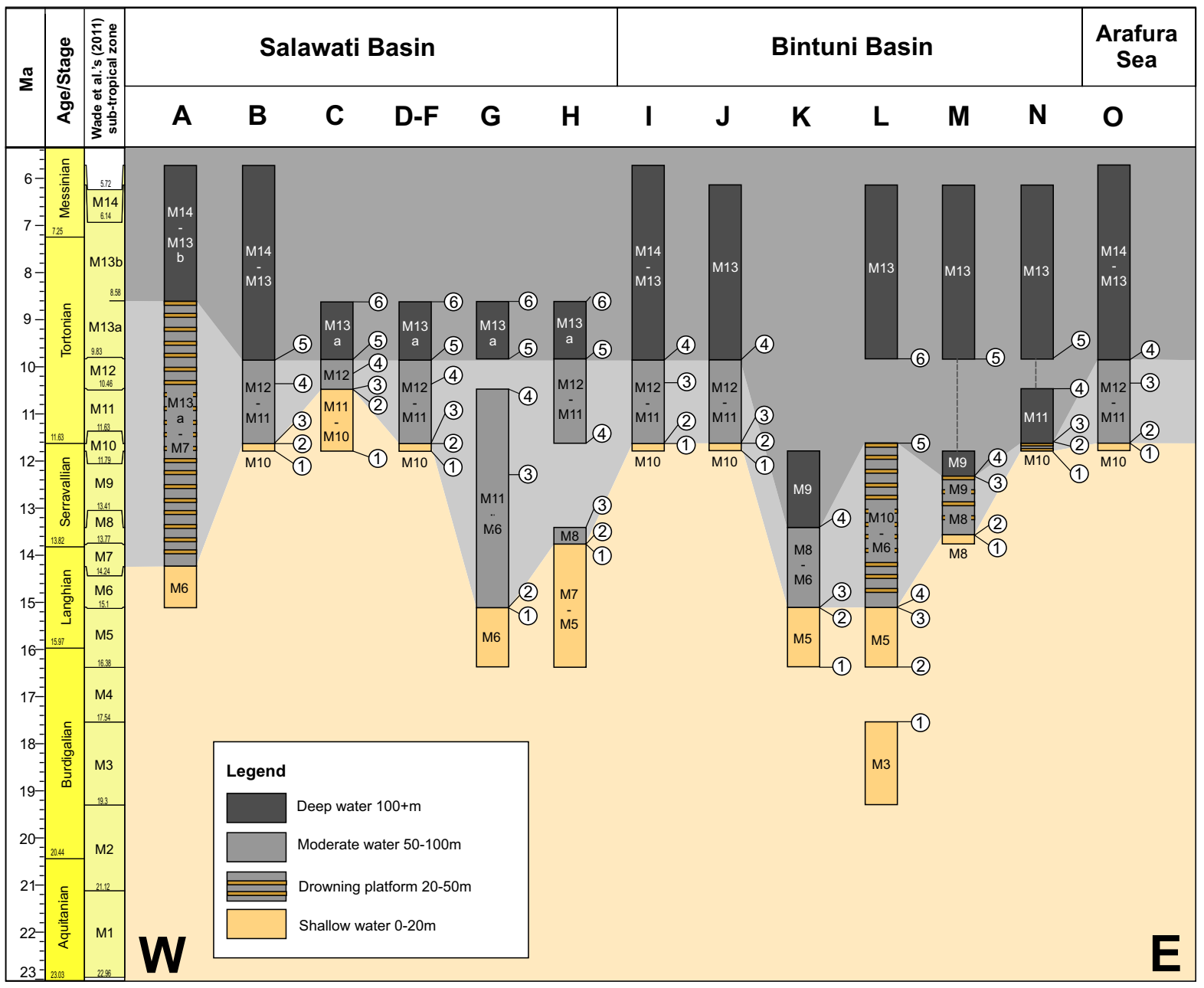

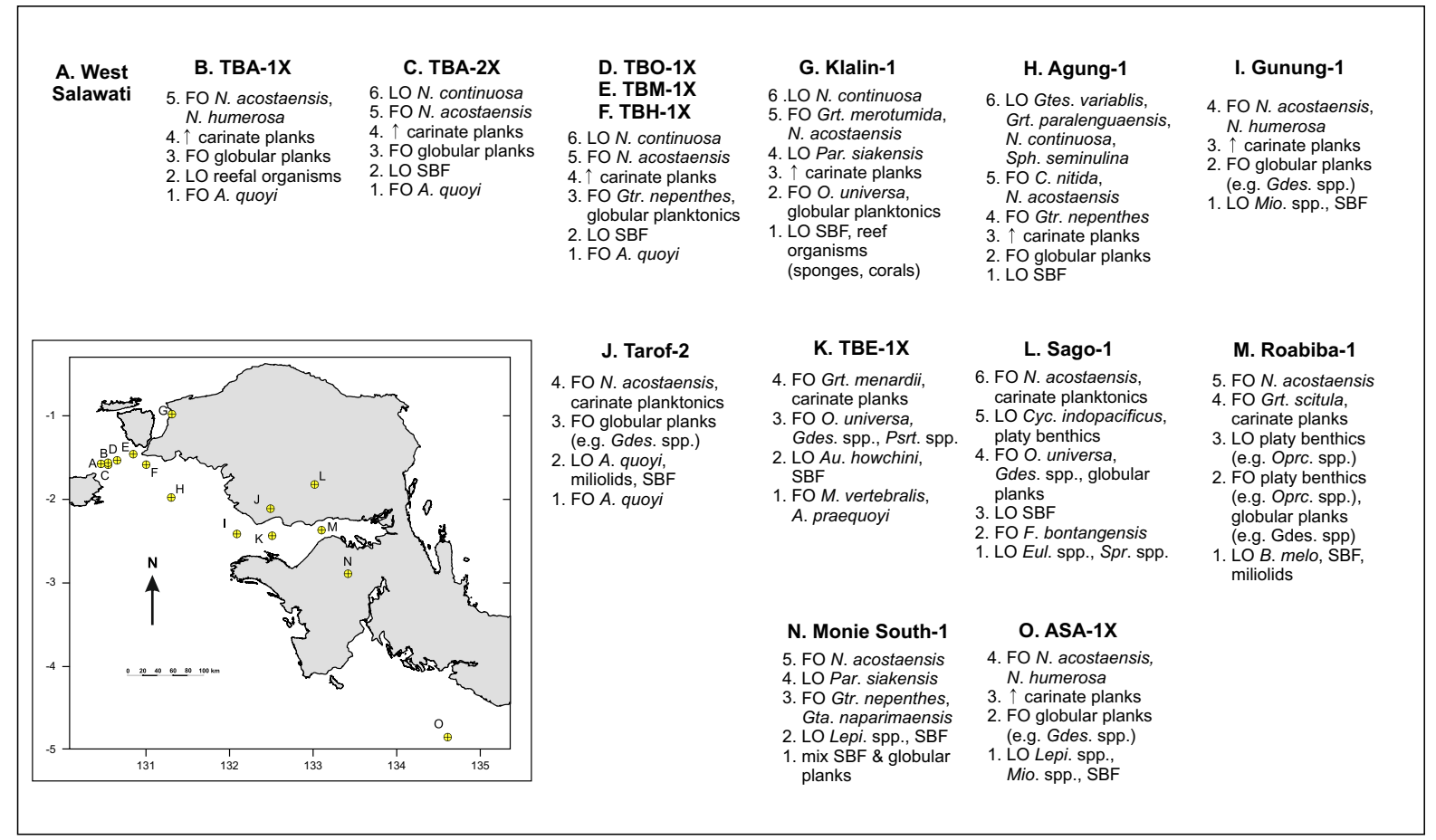


\Fig. 8 Faunal turnover of shallow-water foraminifera replaced by increasingly deeper-water forms as recorded in 15 wells. Planktonic foraminiferal biozones based on Wade et al. (2011) zonation scheme. Zonal boundaries marked by changes in age or environmental diagnostic taxa. There is a general trend for stable platform deposition to cease by M5 (early Langhian), with the initiation of drowning occurring at M6 (mid Langhian), with the completion of the drowning process by M10 (latest Serravallian) marked by the disappearance of shallow-water or platy benthic foraminifera. Fully deep water in excess of $100 \mathrm{~m}$, dominated by carinate planktonic foraminifera occurs by M13b (mid Tortonian). $F O$ first occurrence, $L O$ last occurrence, $S B F$ shallow benthic foraminifera, A. Alveolinella, Au. Austrotrillina, B. Borelis, C. Candeina, Cyc. Cycloclypeus, Eul. Eulepidina, F. Flosculinella, Ga. Globigerina, Gdes. Globigerinoides, Grt. Globorotalia, Gta. Globigerinita, Gtr. Globoturborotalia, Gtes. Globorotaloides, Lepi. Lepidocyclina, M. Marginopora, Mio. Miogypsina, N. Neogloboquadrina, O. Orbulina, Oprc. Operculina, Par. Paragloborotalia, Psrt. Pseudorotalia, Sph. Sphaeroidinellopsis, Spr. Spiroclypeus)

the drowning process during the Serravallian is denoted by the last up-hole occurrences of moderate-water-depth larger benthic foraminifera, such as Cycloclypeus spp. and Operculina spp. (Fig. 8). The mixed assemblages of planktonic and shallow-water benthic foraminifera in these wells are interpreted to be analogous to the heterolithic beds observed above the Maruni Limestone in the Sungai Anggrisi drowning succession, and other locations observed in the eastern Bird's Head.

Other wells, ASA-1X, Gunung-1, Kalitami-1, Tarof-2, TBA-2X, TBH-1X, TBM-1X, and TBO-1X, record a sudden, rather than gradual, change in facies at the end of the Serravallian (M10, 11.79-11.63 Ma; Fig. 8). This is denoted by the presence of Alveolinella quoyi and last up-hole occurrences of other shallow-water foraminifera such as lepidocyclinids and miogypsinids, immediately overlain by facies with wholly planktonic foraminiferal assemblages (Fig. 8).

In many wells, basal planktonic foraminiferal assemblages are dominated by 'moderate-water' taxa (e.g., Bé and Tolderlund 1971; Bé 1977) becoming increasingly dominated by carinate and other 'deep-water' taxa such as Globorotalia spp., Neogloboquadrina spp. and Sphaeroidinellopsis spp. up-hole (e.g., Bé and Tolderlund 1971; Bé 1977). Fully deep-water conditions, with water depths in excess of $100 \mathrm{~m}$, are interpreted to have occurred by the middle Tortonian (M13b, 8.58-6.14 Ma), often denoted by Globorotalia merotumida, Neogloboquadrina acostaensis, $N$. continuosa, and N. humerosa (Fig. 8).

In the Salawati Basin, pinnacle reefs at the top of the Kais Platform are younger towards the west of the basin than in the east (Fig. 8). The uppermost strata of the 'U' Interval are described to be N16 age in the west (recalibrated to Wade et al. (2011) sub-tropical zone M13a, 9.83-8.58 Ma), and N9-N16 (recalibrated to Wade et al. (2011) sub-tropical zones M6-M13a, 15.1-8.58 Ma), in the east (Satyana 2003), marking the time at which platform drowning in the Salawati Basin was complete.

Data from outcrop collected by this study indicates that the drowning process was complete by the end of subtropical planktonic foraminiferal zone M10, and the $\mathrm{Tf} 3 / \mathrm{Tg}$ boundary (11.63 Ma) of the Indo-Pacific Letter Stages, in areas farther to the east of the Bird's Head (e.g., Fig. 2, Columns C-F). However, in the Salawati Basin to the west, the drowning process is interpreted to be complete by the end of sub-tropical zone M13a (8.58 Ma). These observations suggest that the drowning unconformity formed diachronously, younging to the west from M10 (11.63 Ma) to M13a (8.58 Ma) times, over a period of approximately $3 \mathrm{Ma}$ (Figs. 2, 8). This substantiates outcrop evidence from the mainland Bird's Head where migrating facies belts indicate the backstepping of shallow-water facies to the northwest during the Early to Late Miocene (Fig. 7), further supporting diachronous formation of the drowning unconformity as younging towards the west. In the eastern Bintuni Basin, evidence from the Aroba, Jamusura and Besiri River wells (Rossetter 1976) indicates that termination of Kais platform growth occurred in the Middle Miocene (Pigram et al. 1982). However, this diachroneity is also shown in the western Bintuni Basin where the Kais Formation is indicated as continuing into the Late Miocene (Koesoemadinata 1976; Collins 1977; Chevallier and Bordenave 1986; Dolan and Hermany 1988). In the Bintuni Basin, diachroneity is interpreted to occur as subsidence migrated westwards away from the developing LFTB (Collins 1977).

\section{Mechanisms for northern New Guinea regional relative sea-level rise}

Gibson-Robinson and Soedirdja (1986) attributed the cause of the termination of Kais Platform and pinnacle reef growth in the Salawati Basin to a minor regression or still-stand that prevented further growth, leading to erosion. During subsequent renewed transgression, platform reef growth was not re-established (Gibson-Robinson and Soedirdja 1986). However, we consider that favorable conditions during renewed transgression following a minor regression or still-stand should have enabled the platform to re-colonize and continue to grow. Empirical evidence for platform drowning along Sungai Anggrisi is derived from facies and micropaleontological analyses of logged outcrop sections. This evidence indicates that a reduction in carbonate accumulation rates through environmental deterioration, outpaced by the rate of relative sea-level rise, is responsible for the formation of similar drowning successions observed in wells from the western Bird's Head, comparable to the 'U' Interval of the Salawati Basin. 
The mechanism for the increase in rate of relative sealevel rise is unknown. However, rotation of the Philippine Sea Plate, initiating at about $20 \mathrm{Ma}$, and minor subduction close to the northern New Guinea margin related to extrusion of 11-12 Ma volcanic rocks in the Bird's Head (Hall and Spakman 2015), could have driven an acceleration in subsidence in extensional domains. This may have led to an increase in rate of relative sea-level rise contributing to platform drowning. In the Salawati Basin, Late Miocene termination of the Kais platform is attributed to tectonic subsidence commencing at about $6 \mathrm{Ma}$, with an estimated subsidence rate of approximately of $1 \mathrm{~km}$ per million years in the area of the Waipili-1 well (Livingstone 1992).

Extension is interpreted to have occurred across the Bird's Head during most of the Miocene, initiating in the Burdigalian and continuing into the Tortonian. This is supported by biostratigraphic data collected and reviewed by this study, and the presence of sequences, several km thick, of middle and late Miocene siliciclastic strata within the regional basins, including the Salawati Basin, described by Visser and Hermes (1962). However, the entire region has undergone subsequent compressional deformation, which overprints the original shallow-water sequences that are now well above sea-level. The timing of the onset of compressional deformation is controversial; however, we believe that it initiated with the onset of uplift of the LFTB of the Bird's Neck, and mountains of the Central Ranges (Fig. 1) across the Bird's Body during the latest Tortonian-Messinian (Hill and Gleadow 1989; Cloos et al. 2005; Spakman and Hall 2010; Bailly et al. 2011; Hall 2012), after the drowning of the NGLG carbonate platform.

\section{Conclusions}

Although outcrops studied in the eastern Bird's Head are several hundred kilometers away from wells studied in western New Guinea, the similar facies, paleobathymetry, and age of faunal turnover in both regions indicate that carbonate platform drowning was widespread across the entire Bird's Head region. The identification of drowning successions farther to the east of the Salawati and Bintuni Basins, and Sekau Formation type locality, is significant, as it implies the New Guinea drowning event was a widespread environmental crisis during the Middle and Late Miocene.

The interbedded deep-water marl and argillaceous carbonates described from the ' $U$ interval' and Sekau Formation are similar to alternating beds of the same lithologies observed in Sungai Anggrisi. This is significant, as drowning successions such as the Sekau Formation, which contains commercial oil in the western Bird's Head (Visser and Hermes 1962), may extend to the east. Heterolithic successions of the ' $U$ ' Interval in the Salawati Basin record the attempt of carbonate platform strata to keep-up with an increase in the rate of middle Miocene relative sea-level rise. Although the review of well data did not permit identification of Fe-enriched intervals, and thus interpretation of environmental deterioration through nutrification, the failure of platform accumulation to keep pace with the rate of relative sea-level rise is recorded by the formation of a drowning unconformity interpreted to be marked by the ' $U$ ' Marker.

The drowning process is interpreted to have lasted c. 9.5 My, initiating at approximately 18.0 Ma during subtropical planktonic foraminiferal zone M3 (19.3-17.54 Ma). Drowning unconformity formation occurred diachronously, younging towards the north and west over a period of c. $3 \mathrm{My}$. In areas to the east of the Bird's Head, the drowning unconformity is interpreted to have formed at $11.63 \mathrm{Ma}$; however, this surface is dated at $8.58 \mathrm{Ma}$ in areas farther west.

A combination of a reduction in carbonate accumulation rates, through a change from oligo- to meso- trophic conditions (e.g., Brandano et al. 2016), and submergence through relative sea-level rise attributed to extensional tectonics, is interpreted to be responsible for the demise of the New Guinea Limestone platform (e.g., Hallock and Schlager 1986; Sattler et al. 2009). Evidence for submergence is recorded as a gradual increase in bathymetry from environmental preferences of foraminifera, either through short-term high-amplitude oscillations in the global glacioeustatic sea-level trend or localized tectonic subsidence. Although regional tectonics and environmental deterioration are interpreted as a major control on the rise of relative sea-level in the Bird's Head, biostratigraphic dating of the exposed drowning successions in the study area permit a general correlation with recognized Miocene global cycles of sea-level change (e.g., Miller et al. 2005; Snedden and Liu 2010). These sequences correlate with a long-term trend of global sea-level rise from the late Oligocene, with several high-amplitude oscillations throughout the early to middle Miocene, reaching a peak of ca. $80 \mathrm{~m}$ above present sealevel in the early to middle Tortonian at the Tor 1 maximum flooding surface (Snedden and Liu 2010). However, caution is required in attempting to correlate global sea-level trends with stratigraphy in Southeast Asia. This region has been the site of major tectonic events throughout the Neogene, resulting in localized areas of subsidence, uplift, and therefore relative sea-level changes. Nevertheless, onset of glacioeustasy in the Miocene could well mean that a eustatic signal began to act as a significant control on Miocene strata, even in this tectonically active area.

Acknowledgements This work was supported by the Southeast Asia Research Group at Royal Holloway, funded by a consortium of oil companies. We would like to thank TGS for providing multibeam and seismic data, the Institut Teknologi Bandung, particularly Ramadhan Adhitama and Ferry Yulien, Ministry for Research and Technology (Indonesia) and University of Papua for providing data and assistance 
during fieldwork, and staff members at Royal Holloway, University of London, for enabling this study to take place. In particular, we would like to thank Robert Hall for continued mentoring, guidance, helpful discussion, and facilitating the progression of our understanding of a geologically complex and exciting region of the world through his work with the Southeast Asia Research Group. Finally, we would like to thank Kevin Hill, Lloyd White, Maurice Tucker, and two anonymous reviewers whose constructive comments improved this manuscript.

Open Access This article is distributed under the terms of the Creative Commons Attribution 4.0 International License (http://creativecommons.org/licenses/by/4.0/), which permits unrestricted use, distribution, and reproduction in any medium, provided you give appropriate credit to the original author(s) and the source, provide a link to the Creative Commons license, and indicate if changes were made.

\section{References}

Adams CG (1970) A reconsideration of the East Indian letter classification of the Tertiary, Bulletin of the British Museum (Natural History). Geology 19:87-137

Ali JR, Hall R (1995) Evolution of the boundary between the Philippine Sea Plate and Australia: palaeomagnetic evidence from eastern Indonesia. Tectonophysics 251(1-4):251-275

Atmawinata S, Ratman N (1982) Struktur geologi Pulau Yapen dan hubungannya dengan Lajur Sesar Sorong (Geological structure of Yapen Island and its relation with the Sorong Fault). In: Proceedings Indonesian Association of Geologists, Eleventh Annual Convention, 1-6

Atmawinata S, Ratman N, Pieters PE (1989) Geologi Lembar Yapen, Irian Jaya (Geology of the Yapen Sheet area, Irian Jaya). Geological Research and Development Centre, Indonesia

Bailly V, Ringenbach JC, De Sigoyer J, Pubellier M (2011) The Bird's neck: new data, new interpretation. In: Proceedings, Indonesian Petroleum Association Thirty-Fifth Annual Convention and Exhibition IPA11-G-229

Bé AWH (1977) An ecological, zoogeographic and taxonomic review of recent planktonic foraminifera. In: Ramsey ATS (ed) Oceanic micropalaeontology. Academic Press, London, pp 1-100

Bé AWH, Tolderlund DS (1971) Distribution and ecology of living planktonic foraminifera in surface waters of the Atlantic and Indian Oceans. In: Funnell BM, Riedel WR (eds) The micropaleontology of oceans. Cambridge University Press, Cambridge, pp 105-149

Bertoni C, Garcia JA (2012) Interplay between submarine depositional processes and recent tectonics in the Biak Basin, Western Papua, Eastern Indonesia. Berita Sedimentol 23:42-45

Blomeier DP, Reijmer JJ (1999) Drowning of a Lower Jurassic carbonate platform: Jbel Bou Dahar, High Atlas, Morocco. Facies 41(1):81-110

Bock Y, Prawirodirdjo L, Genrich JF, Stevens CW, McCaffrey R, Subarya C, Puntodewo SSO, Calais E (2003) Crustal motion in Indonesia from global positioning system measurements. J Geophys Res 108(B8):2367

Bosence D, Cross N, Hardy S (1998) Architecture and depositional sequences of tertiary fault-block carbonate platforms; an analysis from outcrop (Miocene, Gulf of Suez) and computer modelling. Mar Pet Geol 15(3):203-221

BouDagher-Fadel MK (2008) Evolution and geological significance of larger benthic foraminifera. Developments in palaeontology and stratigraphy 21. Elsevier, Amsterdam, p 544
BouDagher-Fadel MK (2015) Biostratigraphic and geological significance of planktonic foraminifera. UCL Press, London, p 306

Brandano M, Corda L, Tomassetti L, Tagliavento M (2016) Frequency analysis across the drowning of a lower Jurassic Carbonate Platform: the Calcare Massiccio formation (Apennines, Italy). Mar Pet Geol 78:606-620

Brash RA, Henage LF, Harahap BH, Moffat DT, Tauer RW (1991) Stratigraphy and depositional history of the New Guinea Limestone Group, Lengguru, Irian Jaya. In: Proceedings, Indonesian Petroleum Association Twelfth Annual Convention and Exhibition, 67-84

Burgess PM, Hovius N (1998) Rates of delta progradation during highstands: consequences for timing of deposition in deep-marine systems. J Geol Soc London 155:217-222

Burgess PM, Winefield P, Minzoni M, Elders C (2013) Methods for identification of isolated carbonate buildups from seismic reflection data. AAPG Bull 97(7):1071-1098

Catuneanu O (2006) Principles of sequence stratigraphy. Elsevier, Amsterdam, p 386

Charlton TR (1996) Correlation of the Salawati and Tomori Basins, eastern Indonesia: a constraint on left-lateral displacements of the Sorong fault zone. In: Hall R, Blundell D (eds) Tectonic evolution of Southeast Asia, vol 106. Geological Society Special Publication, London, pp 465-481

Charlton TR (2010) The Pliocene-recent anticlockwise rotation of the Bird's Head, the opening of the Aru trough-Cenderawasih bay sphenochasm, and the closure of the Banda double arc. In: Proceedings of the Thirty-Fourth Indonesian Petroleum Association convention and exhibition, IPA10-G-008

Chevallier B, Bordenave ML (1986) Contribution of geochemistry to the exploration in the Bintuni Basin, Irian Jaya. In: Proceedings, Indonesian Petroleum Association Fifteenth Annual Convention and Exhibition, 439-460

Cloos M, Sapiie B, Van Ufford AQ, Weiland RJ, Warren PQ, McMahon TP (2005) Collisional delamination in New Guinea: the geotectonics of subducting slab breakoff. Geological Society of America Special Paper 400, 46

Collins, JL, Qureshi MK (1977) Reef exploration in the Bintuni Basin and Bomberai Trough-Irian Jaya. In: Proceedings, Indonesian Petroleum Association Sixth Annual Convention and Exhibition, 43-66

Costa KM, McManus JF, Anderson RF, Ren H, Sigman DM, Winckler G, Fleisher MQ, Marcantonio F, Ravelo AC (2016) No iron fertilization in the equatorial Pacific Ocean during the last ice age. Nature 529(7587):519-522

Darman H, Sidi FH (2000) An outline of the geology of Indonesia. Indonesian Association of Geologists, Jakarta, pp 1-192

Decker J, Bergman SC, Teas PA, Baillie P, Orange DL (2009) Constraints on the tectonic evolution of the Bird's Head, West Papua, Indonesia. In: Proceedings, Indonesian Petroleum Association Thirty-Third Annual Convention and Exhibition IPA09-G-139, 491-514

Dewey JF, Bird JM (1970) Mountain belts and the new global tectonics. J Geophys Res 75(14):2625-2647

Dickson JAD (1966) Carbonate identification and genesis as revealed by staining. J Sediment Res 36(2):491-505

Dolan PJ, Hermany (1988) The geology of the Wiriagar field, Bintuni basin, Irian Jaya. In: Proceedings, Indonesian Petroleum Association Seventeenth Annual Convention and Exhibition, IPA88$11.14,53-87$

Dow DB (1977) A geological synthesis of Papua New Guinea. Bureau Miner Resour Aust Bull 201:1-41

Dow DB, Hartono U (1982) The nature of the crust underlying Cenderawasih (Geelvink) Bay, Irian Jaya. In: Proceedings, Indonesian Petroleum Association Eleventh Annual Convention and Exhibition, 203-210 
Dow DB, Sukamto R (1984) Western Irian Jaya: the end product of oblique plate convergence in the late Tertiary. Tectonophysics 106:109-139

Drzewiecki PA, Simo JA (1997) Carbonate platform drowning and oceanic anoxic events on a mid-Cretaceous carbonate platform, south-central Pyrenees, Spain. J Sediment Res 67(4):698-714

Erlich RN, Barret SF, Ju GB (1990) Seismic and geologic characteristics of drowning events on carbonate platforms. AAPG Bull 74(10):1523-1537

Erlich RN, Longo AP, Hyare S (1993) Response of carbonate platform margins to drowning: evidence of environmental collapse. In: Loucks RG, Sarg JF (eds) Carbonate sequence stratigraphy, vol 57. American Association of Petroleum Geologists Memoir, Tulsa, pp 241-266

Föllmi KB, Gainon F (2008) Demise of the northern Tethyan Urgonian carbonate platform and subsequent transition towards pelagic conditions: the sedimentary record of the Col de la Plaine Morte area, central Switzerland. Sediment Geol 205(3):142-159

Föllmi KB, Weissert H, Bisfing M, Funk H (1994) Phosphogenesis, carbon-isotope stratigraphy, and carbonate platform evolution along the Lower Cretaceous northern Tethyan margin. Geol Soc Am Bull 106:729-746

Fraser TH, Bon J, Samuel L (1993) A new dynamic Mesozoic stratigraphy for the west Irian micro-continent, Indonesia, and its implications. In: Proceedings of the Indonesian Petroleum Association Twenty-Second Annual Convention, 707-761

Geider RJ, La Roche J (1994) The role of iron in phytoplankton photosynthesis, and the potential for iron-limitation of primary productivity in the sea. Photosynth Res 39(3):275-301

Gibson-Robinson C, Soedirdja H (1986) Transgressive development of Miocene reefs, Salawati Basin, Irian Jaya. In: Proceedings, Indonesian Petroleum Association Fifteenth Annual Convention and Exhibition, 377-403

Gold DP, Hall R, Burgess P, BouDagher-Fadel MK (2014) The Biak Basin and its setting in the Bird's Head region of West Papua. In: Proceedings, Indonesian Petroleum Association Thirty-Eighth Annual Convention and Exhibition, IPA14-G-298, 448-460

Gradstein FM, Ogg JG, Schmitz MD, Ogg GM (2012) The geologic time scale 2012, vol 1-2. Elsevier, Amsterdam, pp 1-1144

Hall R (2002) Cenozoic geological and plate tectonic evolution of SE Asia and the SW Pacific: computer-based reconstructions, model and animations. J Asian Earth Sci 20:353-431

Hall R (2012) Late Jurassic-Cenozoic reconstructions of the Indonesian region and the Indian Ocean. Tectonophysics 570-571:1-41

Hall R, Spakman W (2015) Mantle structure and tectonic history of SE Asia. Tectonophysics 658:14-45

Hallock P (1988) The role of nutrient availability in bioerosion: consequences to carbonate buildups. Palaeogeogr Palaeoclimatol Palaeoecol 63:275-291

Hallock P, Glenn EC (1986) Larger foraminifera: a tool for paleoenvironmental analysis of Cenozoic carbonate depositional facies. Palaios 1(1):55-64

Hallock P, Schlager W (1986) Nutrient excess and the demise of coral reefs and carbonate platforms. Palaios 1:389-398

Hamilton W (1979) Tectonics of the Indonesian Region. U.S. Geological Survey Professional Paper, 1-1078

Handford CR, Loucks RG (1993) Carbonate depositional sequences and systems tracts-responses of carbonate platforms to relative sea-level changes. In: Loucks RG, Sarg JF (eds) Carbonate sequence stratigraphy, vol 57. American Association of Petroleum Geologists, Memoir, Tulsa, pp 3-41

Hill KC, Gleadow AJW (1989) Uplift and thermal history of the Papuan Fold Belt, Papua New Guinea: apatite fission track analysis. Aust J Earth Sci 36(4):515-539

Hill KC, Hall R (2003) Mesozoic-Cainozoic evolution of Australia's New Guinea Margin in a west Pacific context. In: Hillis R,
Müller RD (eds) Defining Australia: the Australian plate as part of planet earth. Geological Society of Australia Special Publication 22 and Geological Society of America Special Paper 372, Boulder, 265-290

Iaccarino SM, Premoli Silva I, Biolzi M, Foresi LM, Lirer F, Turco E, Petrizzo MR (2007) Practical manual of Neogene planktonic foraminifera. International School on Planktonic Foraminifera VI course, Neogene

Kim W, Fouke BW, Petter AL, Quinn TM, Kerans C, Taylor F (2012) Sea-level rise, depth-dependent carbonate sedimentation and the paradox of drowned platforms. Sedimentology 59:1677-1694

Klootwijk C, Pigram C, Giddings J (1986) Pilot paleomagnetic results from the Bird's Head, Irian Jaya, In: IOC Symposium on Marine Science in the Western Pacific: The Indo-Pacific convergence: Townsville, Intergovernmental Oceanographic Commission, 21

Koesoemadinata RP (1976) Tertiary carbonate sedimentation in Irian Jaya with special reference to the northern part of the Bintuni Basin. In: Proceedings of the Indonesia Petroleum Association Carbonate Seminar, 79-92

Livingstone HJ (1992) Hydrocarbon source and migration, Salawati Basin, Irian Jaya. Eastern Indonesia Exploration Symposium, Simon Petroleum Technology/Pertamina

Livingstone HJ, Sincock BW, Syarief AM, Sriwidadi, Wilson JN (1992) Comparison of Walio and Kasim reefs, Salawati Basin, western Irian Jaya, Indonesia. In: Proceedings of the Indonesian Petroleum Association Carbonate rocks and reservoirs of Indonesia-a core workshop

Longman MW, Maxwell RJ, Mason ADM, Beddoes LRJ (1987) Characteristics of a Miocene intrabank channel in Batu Raja Limestone, Ramba Field, South Sumatra, Indonesia. AAPG Bull 71(10):1261-1273

Lunt P (2013) Foraminiferal micropalaeontology in SE Asia. In: Bowden AJ (ed) Landmarks in foraminiferal micropalaeontology: history and development. The Micropalaeontological Society, Spec. Publ. 6, Geol. Soc., London, pp 193-206

Marino M, Santantonio M (2010) Understanding the geological record of carbonate platform drowning across rifted Tethyan margins: examples from the Lower Jurassic of the Apennines and Sicily (Italy). Sediment Geol 225:116-137

Martin JH, Fitzwater SE (1988) Iron deficiency limits phytoplankton growth in the north-east Pacific subarctic. Nature 331:341-343

Masse JP, Fenerci-Masse M (2011) Drowning discontinuities and stratigraphic correlation in platform carbonates. The late Barremian-early Aptian record of southeast France. Cretac Res 32(6):659-684

McAdoo RI, Haebig JC (1999) Tectonic elements of the north Irian Basin. In: Proceedings, Indonesian Petroleum Association Twenty-Seventh Annual Convention and Exhibition, 1-17

McCaffrey R, Abers GA (1991) Orogeny in arc-continent collision: the Banda arc and western New Guinea. Geology 19:563-566

Memmo V, Bertoni C, Masini M, Alvarez J, Imran Z, Echanove A, Orange D (2013) Deposition and deformation in the recent Biak Basin (Papua Province, Eastern Indonesia). In: Proceedings Indonesian Petroleum Association Thirty-Seventh Annual Convention and Exhibition, IPA13-G-122

Miller KG, Kominz MA, Browning JV, Wright JD, Mountain GS, Katz ME, Sugarman PJ, Cramer BS, Christie-Blick N, Pekar SF (2005) The Phanerozoic record of global sea-level change. Science 310(5752):1293-1298

Milsom J (1991) Gravity measurements and terrane tectonics in the New Guinea region. J SE Asian Earth Sci 6:319-328

Milsom J, Masson D, Nichols G, Sikumbang N, Dwiyanto B, Parson L, Kallagher H (1992) The Manokwari trough and the western end of the New Guinea trench. Tectonics 11(1):145-153 
Mutti M, Droxler AW, Cunningham AD (2005) Evolution of the Northern Nicaragua Rise during the Oligocene-Miocene: drowning by environmental factors. Sediment Geol 175(1):237-258

Najarro M, Rosales I, Martín-Chivelet J (2011) Major palaeoenvironmental perturbation in an Early Aptian carbonate platform: prelude of the Oceanic Anoxic Event 1a? Sediment Geol 235(1):50-71

Pairault AA, Hall R, Elders CF (2003) Structural styles and tectonic evolution of the seram trough, Indonesia. Mar Pet Geol 20:1141-1160

Phoa RSK, Samuel L (1986) Problems of source rock identification in the Salawati Basin, Irian Jaya. In: Proceedings, Indonesian Petroleum Association Fifteenth Annual Convention and Exhibition, 405-421

Pieters PE, Pigram CJ, Trail DS, Dow DB, Ratman N, Sukamto R (1983) The stratigraphy of the western Irian Jaya. Bull Geol Res Dev Centre 8:14-48

Pigram CJ, Davies HL (1987) Terranes and accretion history the New Guinea orogeny. Bur Miner Resour J Aust Geol Geophys 10:193-212

Pigram CJ, Panggabean H (1984) Rifting of the northern margin of the Australian continent and the origin of some microcontinents in eastern Indonesia. Tectonophysics 107:331-353

Pigram CJ, Robinson GP, Tobing SL (1982) Late Cainozoic origin for the Bintuni Basin and adjacent Lengguru Fold Belt, Irian Jaya. In: Proceedings, Indonesian Petroleum Association Eleventh Annual Convention and Exhibition, 109-126

Pownall JM, Hall R, Watkinson IM (2013) Extreme extension across Seram and Ambon, eastern Indonesia: evidence for Banda slab rollback. Solid Earth 4:277-314

Pownall JM, Hall R, Armstrong RA, Forster MA (2014) Earth's youngest known ultrahigh-temperature granulites discovered on Seram, eastern Indonesia. Geology 42(4):279-282

Puntodewo SSO, McCaffrey R, Calais E, Bock Y, Rais J, Subarya C, Poewariardi R, Stevens C, Genrich J, Zwick P, Fauzi, Wdowinski S (1994) GPS measurements of crustal deformation within the Pacific-Australia plate boundary zone in Irian Jaya, Indonesia. Tectonophysics 237:141-153

Redmond JL, Koesoemadinata RP (1976) Walio oil field and the Miocene carbonates of Salawati basin, Irian, Jaya, Indonesia. In: Proceedings, Indonesian Petroleum Association Fifth Annual Convention and Exhibition, 41-57

Rossetter RJ (1976) New Guinea Limestone Group, Bomberai Peninsula, Irian Jaya. Indonesian Petroleum Association Special Publication, Jakarta, pp 93-98

Ruiz-Ortiz PA, Bosence DWJ, Rey J, Nieto LM, Castro JM, Molina JM (2004) Tectonic control of facies architecture, sequence stratigraphy and drowning of a Liassic carbonate platform (Betic Cordillera, Southern Spain). Basin Res 16(2):235-257

Sattler U, Immenhauser A, Schlager W, Zampetti V (2009) Drowning history of a Miocene carbonate platform (Zhujiang Formation, South China Sea). Sediment Geol 219(1):318-331

Satyana AH (2003) Re-evaluation of the sedimentology and evolution of the Kais carbonate platform, Salawati basin, eastern Indonesia: exploration significance. In: Proceedings, Indonesian Petroleum Association Twenty-Ninth Annual Convention and Exhibition, $1-22$

Schlager W (1981) The paradox of drowned reefs and carbonate platforms. Geol Soc Am Bull 92(4):197-211

Schlager W (1989) Drowning unconformities on carbonate platforms. In: Crevello PD, Wilson JL, Sarg JF, Read JF (eds), Controls of carbonate platform and basin development vol 44. SEPM Special Publication, 15-27

Schlager W (1991) Depositional bias and environmental changeimportant factors in sequence stratigraphy. Sediment Geol 70(2-4):109-130
Schlager W (1999) Type 3 sequence boundaries. In: Harris PM, Saller AH, Simo JA (eds), Advances in carbonate sequence stratigraphy: application to reservoirs, outcrops and models vol 63. SEPM Special Publication, 35-45

Sellner KG, Doucette GJ, Kirkpatrick GJ (2003) Harmful algal blooms: causes, impacts and detection. J Ind Microbiol Biotechnol 30(7):383-406

Simone L, Carannante G (1988) The fate of foramol ("temperatetype") carbonate platforms. Sediment Geol 60(1-4):347-354

Snedden JW, Liu C (2010) A compilation of Phanerozoic sea-level change, coastal onlaps and recommended sequence designations. AAPG Search and Discovery Article 40594

Spakman W, Hall R (2010) Surface deformation and slab-mantle interaction during Banda arc subduction rollback. Nat Geosci 3:62-566

Struckmeyer HIM, Yeung M, Pigram CJ (1993) Mesozoic to Cainozoic plate tectonic and palaeogeographic evolution of the New Guinea region. In: Carman GJ, Carman Z (eds), Petroleum exploration in Papua New Guinea. Proceedings of the second PNG Petroleum Convention, Port Moresby, 261-290

Sulli A, Interbartolo F (2016) Subaerial exposure and drowning processes in a carbonate platform during the Mesozoic Tethyan rifting: the case of the Jurassic succession of Western Sicily (central Mediterranean). Sediment Geol 331:63-77

Thorne JA (1992) An analysis of the implicit assumptions of the methodology of seismic sequence stratigraphy. Geol Geophys Cont Margins AAPG Memoir 53:375-394

Tikku A, Subarya C, Masturyono, McCaffrey R, Genrich J (2006) Evidence from GPS data for an Eastern Bird's Head Block in Indonesia. J Geophys Res Solid Earth 3-1

Valenta WT (1979) Seismic modelling of porosity distribution in a Miocene reef, Salawati Island, Indonesia. In: Proceedings, Indonesian Petroleum Association Eighth Annual Convention and Exhibition, 159-176

Van Wagoner JC, Posamentier HW, Mitchum RM et al (1988) An overview of the fundamentals of sequence stratigraphy and key definitions. In: Wilgus CK, Hastings BS, Kendall CGStC, Posamentier HW, Ross CA, van Wagoner JC (eds) Sea level changes: an integrated approach, vol 42. Special Publication Society of Economic Paleontologists and Mineralogists, Tulsa, pp 39-45

Visser WA, Hermes JJ (1962) Koninklijk Nederlands Geologisch Mijnbouwkundig genootschap Verhandelingen Geologische (Geological results of the search for oil in Netherlands New Guinea). Nederlandsche Nieuw Guinee Petroleum Maatschappij

Wade BS, Pearson PN, Berggren WA, Pälike H (2011) Review and revision of Cenozoic tropical planktonic foraminiferal biostratigraphy and calibration to the geomagnetic polarity and astronomical time scale. Earth Sci Rev 104:111-142

Wallace LM, Stevens C, Silver E, McCaffrey R, Loratung W, Hasiata Stanaway R, Curley R, Rosa R, Taugaloidi J (2004) GPS and seismological constraints on active tectonics and arc-continent collision in Papua New Guinea: implications for mechanics of microplate rotations in a plate boundary zone. J Geophys Res Solid Earth 109(5): 1978-2012

Walsh JJ, Steidinger KA (2001) Saharan dust and Florida red tides: the cyanophyte connection. J Geophys Res Oceans 106(C6):11597-11612

Waschmuth W, Kunst F (1986) Wrench fault tectonics in Northern Irian Jaya. In: Proceedings, Indonesian Petroleum Association Fifteenth Annual Convention and Exhibition, 371-375

Watkinson IM, Hall R (2016) Fault systems of the eastern Indonesian triple junction: evaluation of Quaternary activity and implications for seismic hazards. In: Cummins P, Meilano I (eds) Geohazards in Indonesia: earth science for disaster risk reduction. Geological Society, Special Publication, London, p 441 
Weissert H (1989) C-isotope stratigraphy, a monitor of palaeonvironmental change: a case study from the Early Cretaceous. Surv Geophys 10:1-61

Weissert H (1990) Siliciclastics in the Early Cretaceous Tethys and North Atlantic Oceans: documents of periodic Greenhouse climate conditions. In: Cita BM (ed) Geology of the oceans, vol 44. Mem Soc Geol, Bologna, pp 59-69

Weissert H, Lini A, Föllmi KB, Kuhn O (1998) Correlation of Early Cretaceous carbon isotope stratigraphy and platform drowning events: a possible link? Palaeogeogr Palaeoclimatol Palaeoecol 137(3-4):189-203

Williams PR, Amiruddin (1983) Diapirism and deformation east of the Mamberamo river, northern Irian Jaya. In: Proceedings Indonesian Petroleum Association, Twelfth Annual Convention, 67-79

Wilson MEJ (2002) Cenozoic carbonates in Southeast Asia: implications for equatorial carbonate development. Sediment Geol 147:295-428

Wilson JN (2006) Geological summary of the Salawati basin, Irian Jaya. In: Caughey C, Dyer JNJ, Kohar A, Lestarini H, Lodwick
WR, Prijosoesilo P, Wight AWR, Wilson JN (eds), Seismic atlas of Indonesian oil and gas fields Vol II, Java, Kalimantan, Natuna, Irian Jaya. In: Proceedings, Indonesian Petroleum Association, IRJ-1-IRJ-5

Winckler G, Anderson RF, Fleisher MQ, McGee D, Mahowald N (2008) Covariant glacial-interglacial dust fluxes in the equatorial Pacific and Antarctica. Science 320(5872):93-96

Wissler L, Funk H, Weissert H (2003) Response of Early Cretaceous carbonate platforms to changes in atmospheric carbon dioxide levels. Palaeogeogr Palaeoclimatol Palaeoecol 200(1):187-205

Wortmann UG, Weissert H (2000) Tying platform drowning to perturbations of the global carbon cycle with a $\delta 13 \mathrm{COrg}$-curve from the Valanginian of DSDP Site 416. Terra Nova 12(6):289-294

Zempolich WG (1993) The drowning succession in Jurassic Carbonates of the Venetian Alps, Italy: a record of supercontinent breakup, gradual eustatic rise, and eutrophication of shallow-water environments. In: Loucks RG, Sarg JF (eds) Carbonate sequence stratigraphy, vol 57. American Association of Petroleum Geologists, Memoir, Tulsa, pp 63-105 